\title{
THE IMPACT OF AGRICULTURAL LABOR AND WATER RESOURCES ON THE EXPECTED RETURN OF PROPOSED CROPPING PATTERN FOR THE RECLAMATION PROJECT OF MILLION AND HALF MILLION FEDDANS IN EGYPT
}

(Received: 26. 2. 2018)

\author{
By \\ Sally A. H. Bawady

\begin{abstract}
Economic Studies Department, Socio Economic Studies Division, Desert Research Center, Cairo Egypt
\end{abstract}

\begin{abstract}
The agricultural sector is the main pillar of the Egyptian economy, and one of the most productive sectors, on which a large proportion of the population depends. This sector also contributes to both Egyptian Gross Domestic Product (GDP) and the total Egyptian exports. In addition, the problem of determining the expected crop structure is also one of the most important determinants affecting the development of new lands, especially with the presence of more than the composition of the crop issued either from individuals or the state. The research objectives study of the proposed crop structures, whether by individuals or the state for the million and half million feddan proposed reclamation, and to determine the expected results from the application of some of the general productive policies of the state on those crop structures. The present study will cover the Minya Governorate, where it consists of about 620 thousand feddans of land which represents $41.3 \%$ of the total 1.5 million feddans project. Productive policies proposed to be applied to the different cropping pattern of Minya Governorate for the old and new agricultural lands and reclaimed from the project 1.5 million feddans is: First scenario: A proposal for a crop pattern to adopt the policy of selfsufficiency of the main crops, vegetables and fruits in Minya Governorate in 2025 in the light of the scarcity of available labor and water. Second scenario: A proposal for a crop pattern to adopt the policy of reducing the required labor courses by about 20\% in Menia Governorate in 2025 in light of the scarcity of available labor and water. Third scenario: Proposed crop pattern to adopt the policy of expanding livestock production by increasing the area of fodder crops in Minya Governorate in 2025. It is supported by the scarcity of labor and water availability. Fourth scenario: A proposal for a crop pattern to adopt the policy of expansion of food processing by increasing the areas of crops entering the food processing in Minya Governorate in 2025 in the light of the scarcity of available labor and water. Based on the results, there are insignificant deference between scenarios and the best one is the second which reduces the demand on labour by $27 \%$ and the demand of water by $2 \%$ in spite of the reduction of net return by $0.3 \%$.
\end{abstract}

Key words: cropping pattern, goal programming, agricultural labor, water resources.

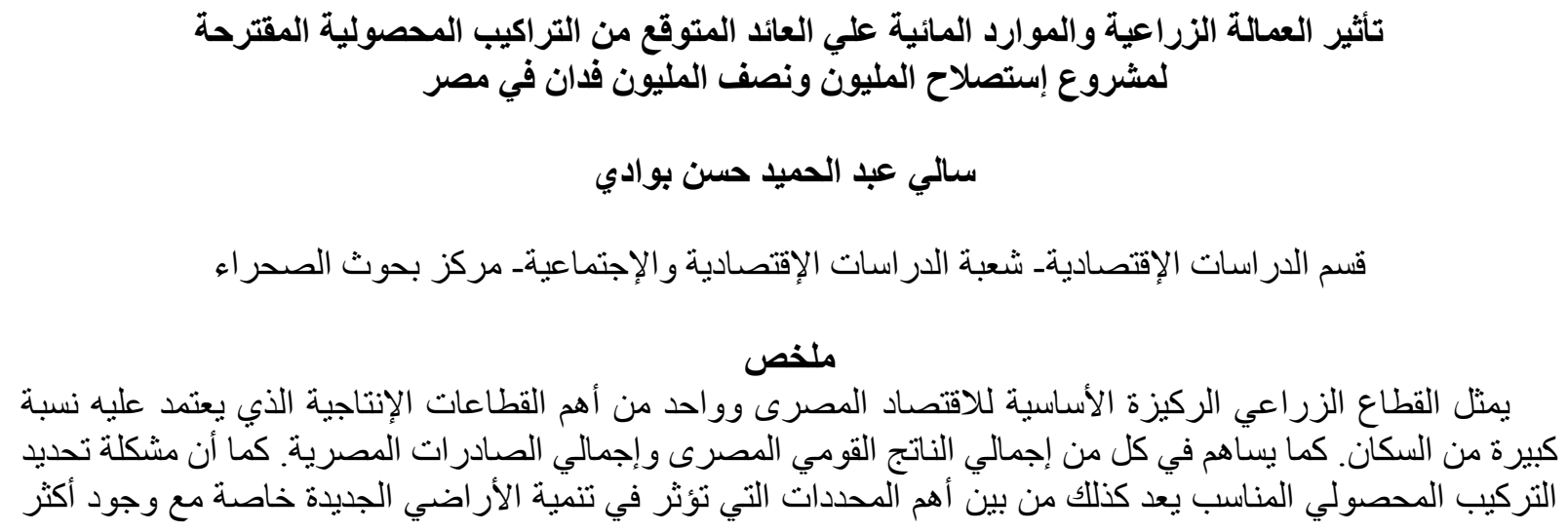




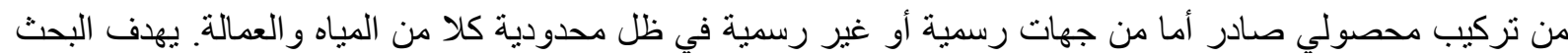

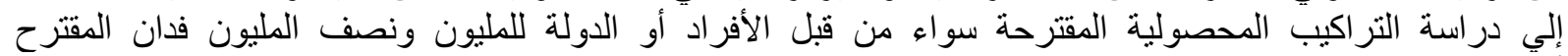

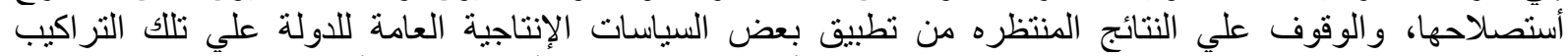

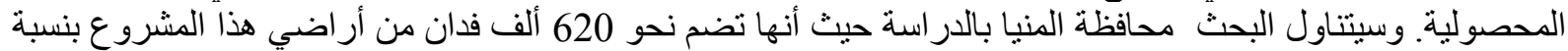

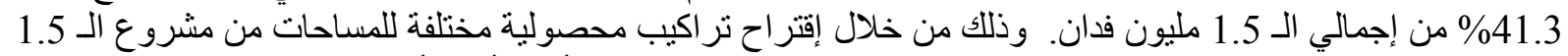

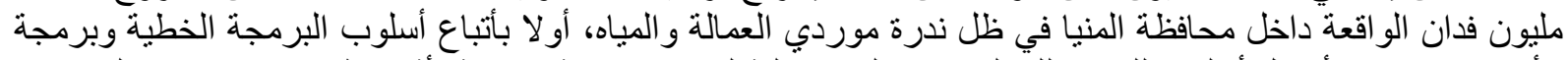

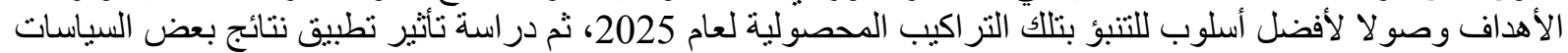

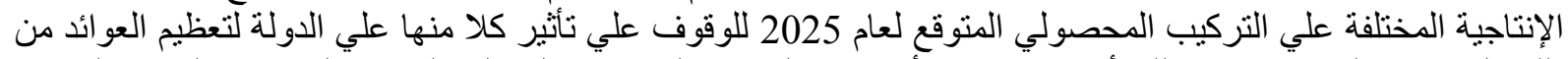

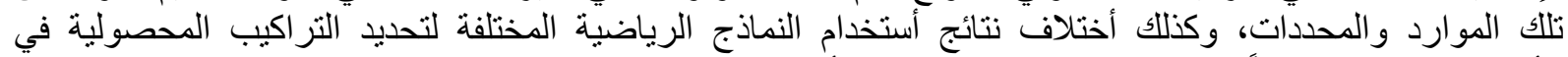

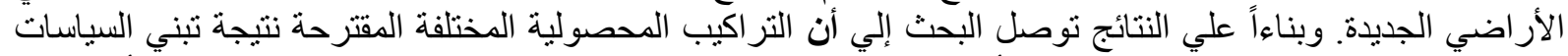

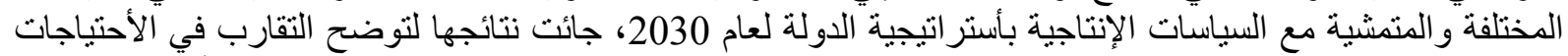

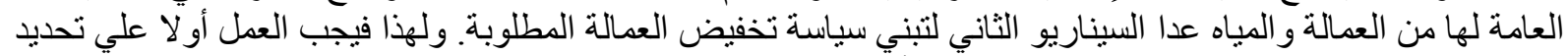
السياسة التي ترغب الدولة في تبنيها نظر التقارب الأحتياجات العيات العامة لكلا من تلكان التر اكيب المحصولية.

خاصة مع وجود أكثر من ثركيب محصولي صادر إما من رئن

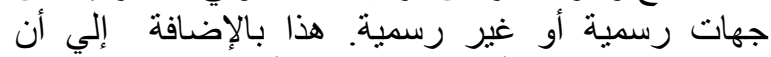

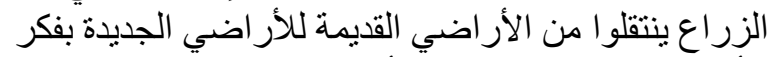

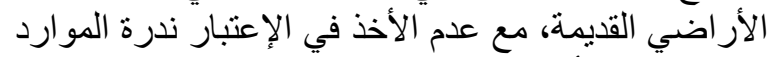

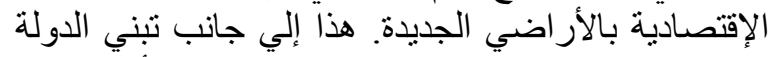

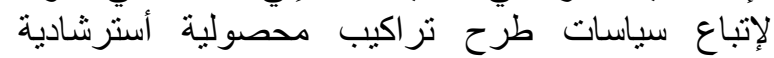

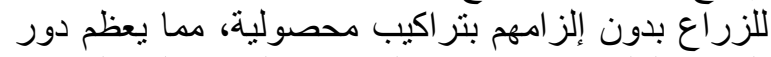

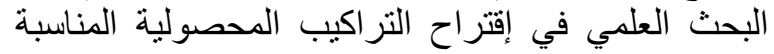

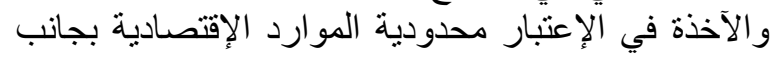
المتغير ات الإقتصادية المحيطة.

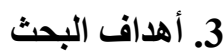

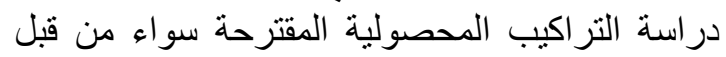

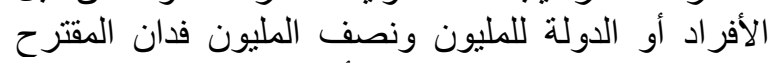

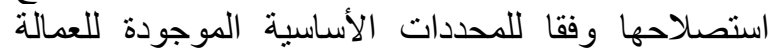

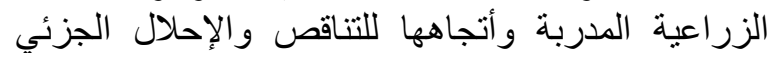

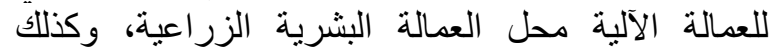

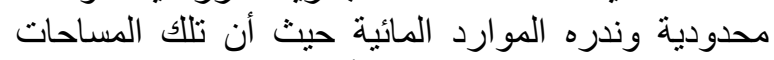

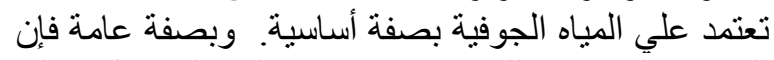

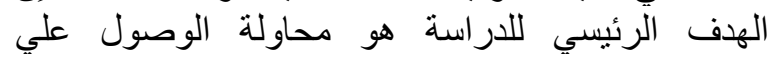

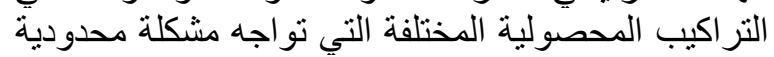

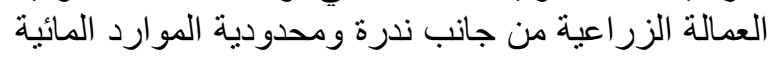

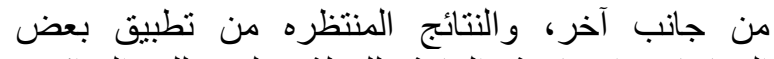

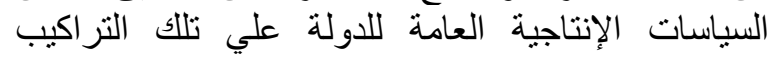

المحصولية.

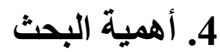

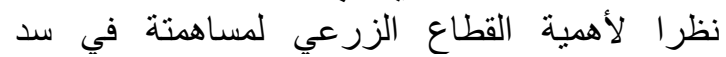

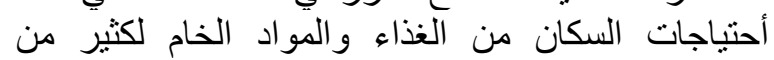

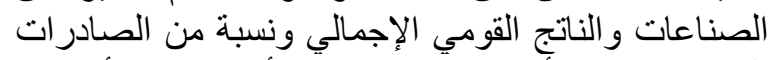

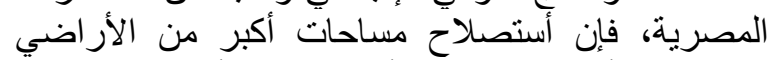
يعتبر من الأهداف القومية الأساسية مع الأخذ في الإعتبار

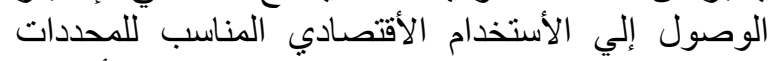

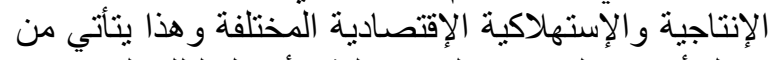
خلال أقتر اح التراكيب المحصولية الأفضل لتلكية المسأحات

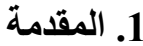

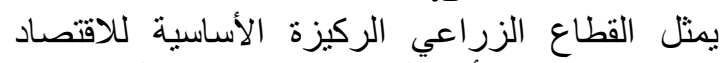

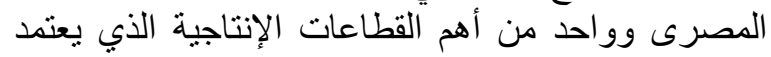

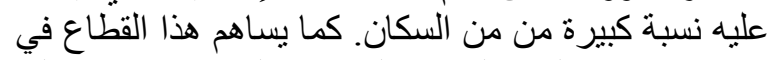

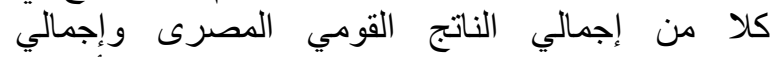

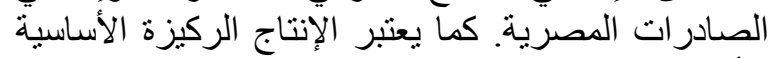

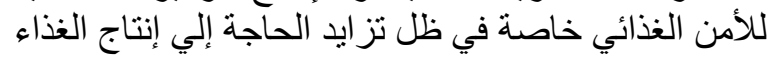

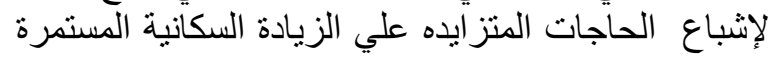
في عدد السكان.

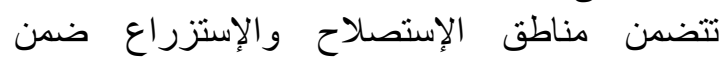

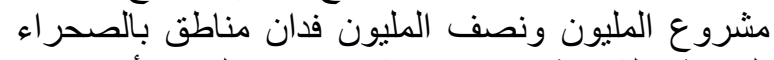

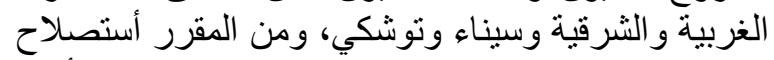

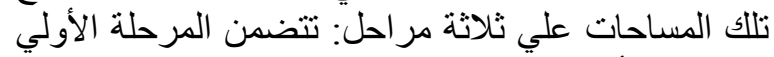

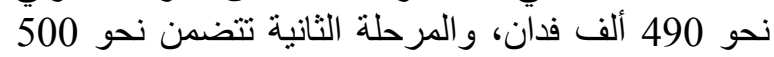

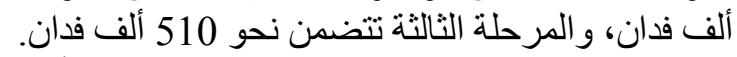

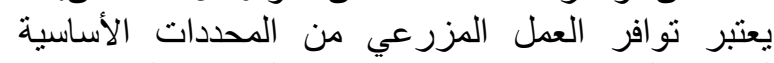

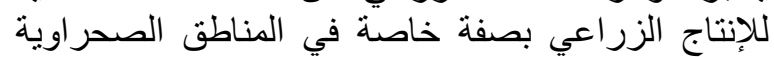

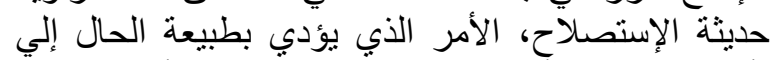

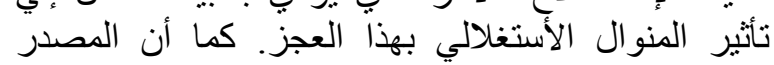

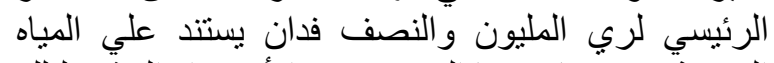

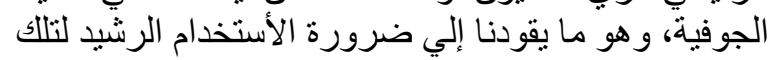

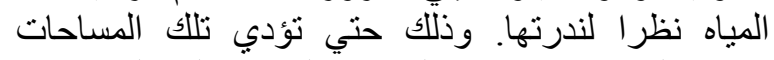

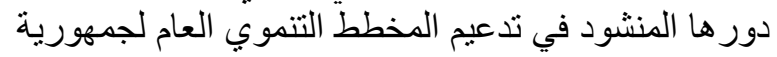

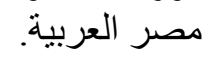

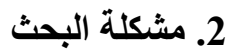

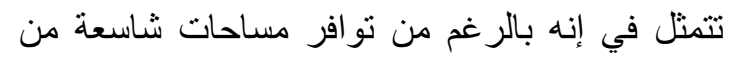

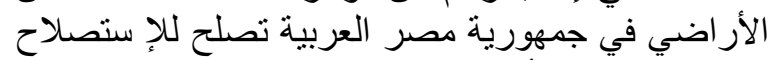

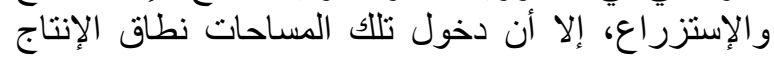
يواجه العديد من المحددات وخاصة الإنة المحددات الإنتاجية

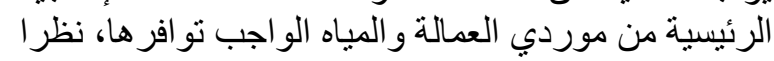

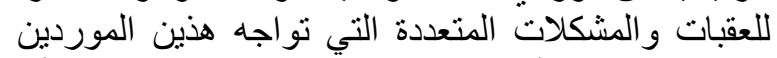

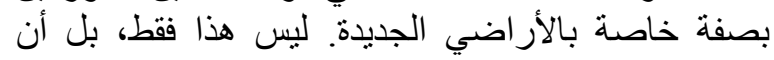

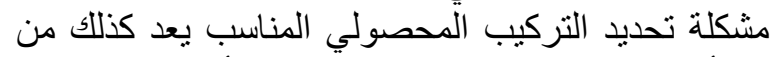

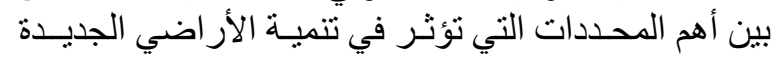




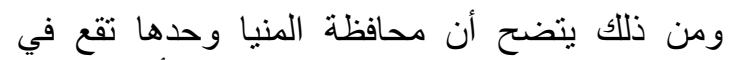

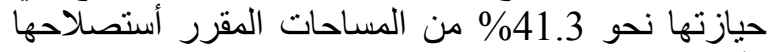

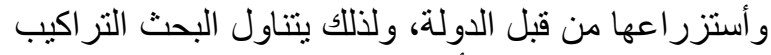

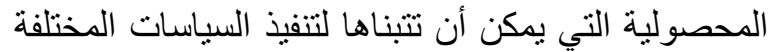

محل الدر اسة حتي عام 2025.

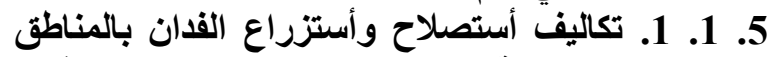

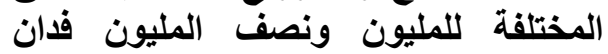

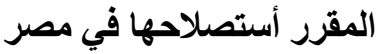

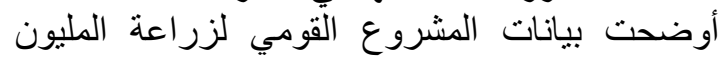

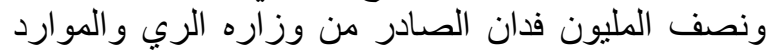

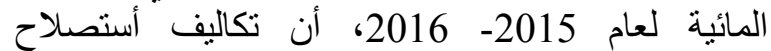
وأستزراع الفدان بالمناطق المختلفة للمحافظات محل

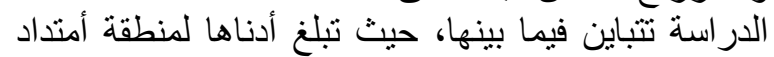

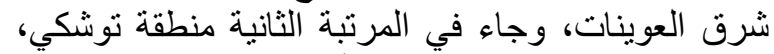

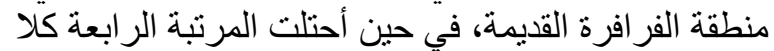

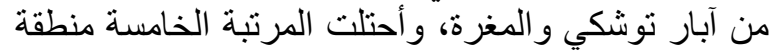

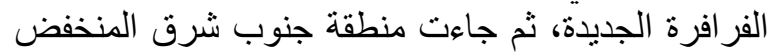

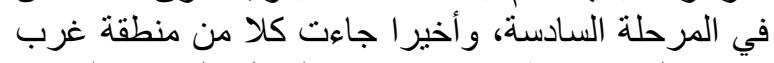
غرب المنيا ومنطقة شرق سيوة لتحتل المرتبة السابعة المابعة

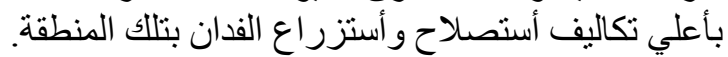

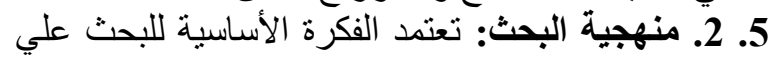

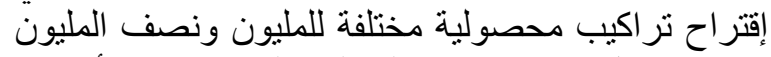

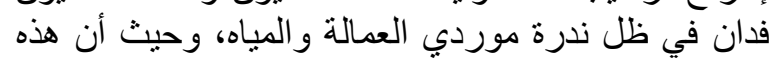

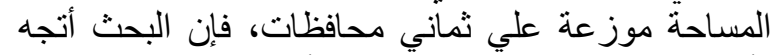

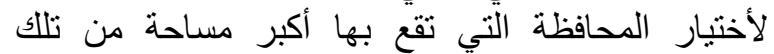

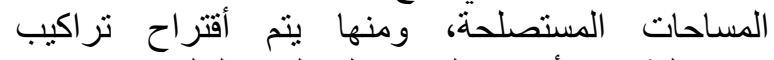
محصولية تخدم أهداف البحث علي النحو التالي:
مع تعظيم العائد من الموارد الإقتصادية المحدودة وهي

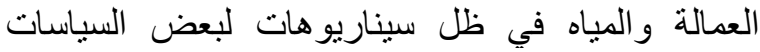
الإقتصادية العامة للاولة.

5. منطقة الدراسة ومنهجية البحثة ومصادة البهادر البيانات

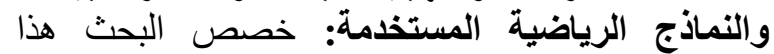

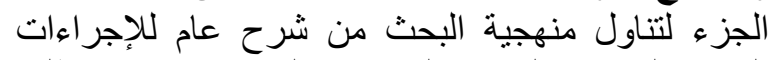

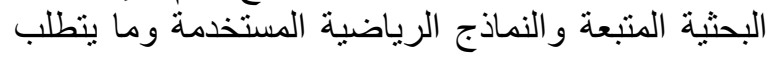

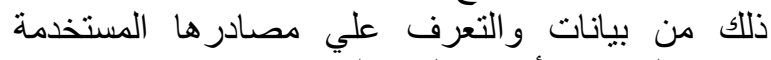
وصو لا لتحقيق الأهداف العامة له. له. 1.5. منطقة الاراسة: تستهدف الخطة الخة العة العامة للادولة أستصلاح و أستزر اع مليون ونصف ملئه مليون فدان موز عيين

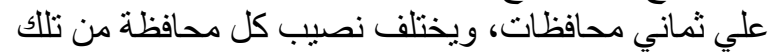

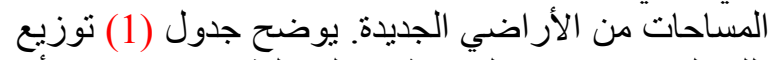

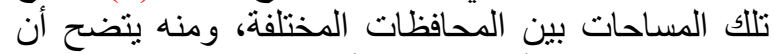

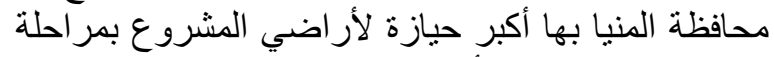

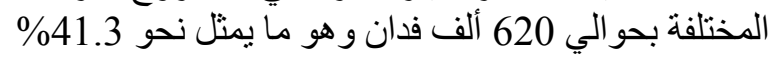

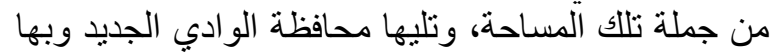
280 ألف فدان بنحو 18.7\% من الإجمالي، ثم محافظة

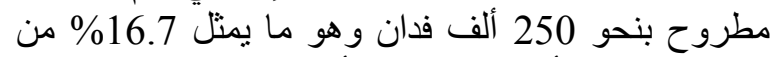

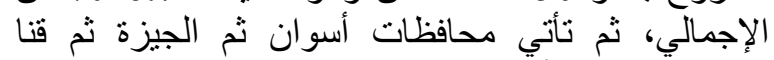

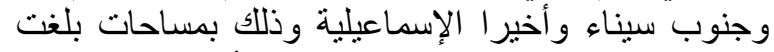

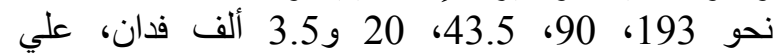

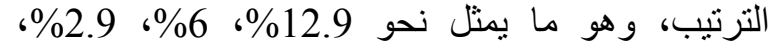

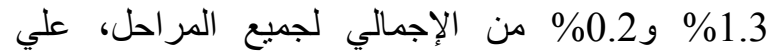
الترتيب.

\begin{tabular}{|c|c|c|c|c|c|}
\hline (الفساحة فدان) & | المحافظة & |لمنظقة & (الف فدانة) & المحافظة & المنطقة \\
\hline 30 & | الو ادي الجديد & | أمتداد الداخلة & \multicolumn{3}{|r|}{ المرحلة الاولي } \\
\hline 25 & أسوان & غرب كوم أمبو & 30 & الو ادي الجديد & الفر افرة القديمة \\
\hline 35 & مطروح & المغرا & 20 & الو ادي الجديد & الفر افرة الجديدة \\
\hline 140 & المنيا & غرب غرب المنيا 1 & 20 & الو ادي الجديد & امتداد الداخلة \\
\hline 40 & 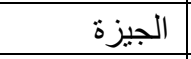 & جنوب شرق المنخفض & 135 & مطروح & 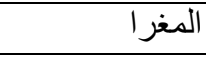 \\
\hline 50 & | الجيزة & جنوب شرق المنخفض1 & 3.5 & الاسماعيلية & قرية الامل \\
\hline 30 & | مطروح & شرق سيوه & 143 & أسو ان & ت ت توشكي \\
\hline 490 & \multicolumn{2}{|r|}{ إجمالي المرحلة الثانية } & 25 & أسوان & آبار توشكي \\
\hline \multicolumn{3}{|r|}{ المرحلة الثالثة } & 25.5 & قنا & المر اشده \\
\hline 40 & |الو ادي الجديد & الفر افرة القديمة & 18 & قنا & المر اشده \\
\hline 50 & مطروح & جنوب شرق المنخفض & 80 & المنيا & غرب غرب \\
\hline 20 & جنوب سيناء & الطور & 500 & \multicolumn{2}{|c|}{ إجمالي المرحلة الأولي } \\
\hline 250 & ال المنيا & غرب المنيا & \multicolumn{3}{|r|}{ المرحلة الثانية } \\
\hline 150 & المنيا & غرب غرب المنيا 2 & 120 & الو ادي الجديد & الفر افرة القديمة \\
\hline 510 & \multicolumn{2}{|r|}{ إجمالي المرحلة الثالثة } & 20 & الو ادي الجديد & الفر افرة الجديدة \\
\hline \multicolumn{3}{|c|}{1500} & \multicolumn{3}{|c|}{ إجمالي المراحل الثلاثة } \\
\hline
\end{tabular}


حديثا للرقعة الزراعية، سيتم العمل من خلال البحث علي لئي

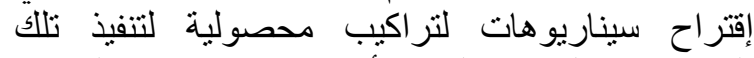

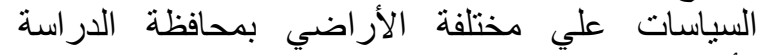

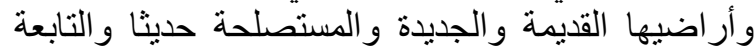

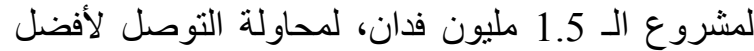

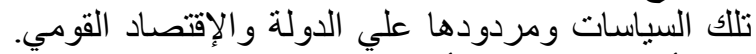
مع الأخذ في الإعتبار أن التراكيب المحصولية المالية المقترحة

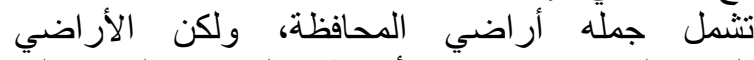
المستصلحة حديثا يوصي بأن تطبق التر اكيب المحصولية الألية

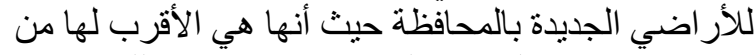

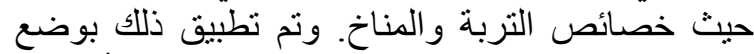

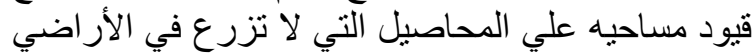

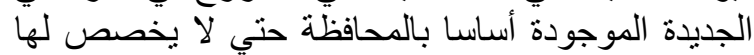

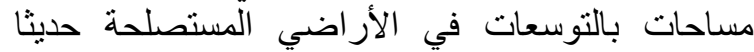

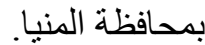

و إعتمادا علي نتائج بعض الإراسات الهامه السابقة

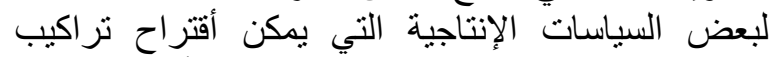

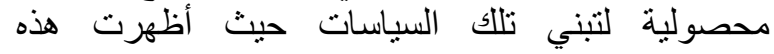
الدراسات ندرة موردي المياه و العمالة في تلإلك المناطق،

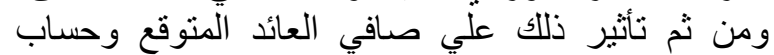
المردود الإقتصادي لتلاك السياسات و والمقارنة بينهم

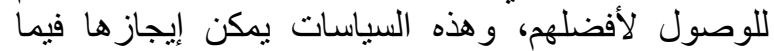

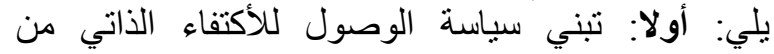

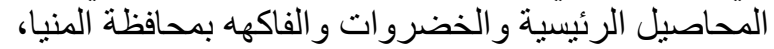
وفيها تم الأعتماد علي أحتياجات الفرد من السلع الأساسية

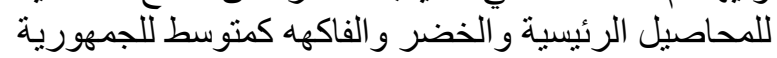

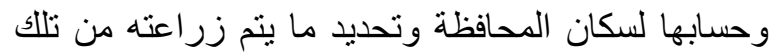

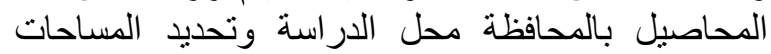

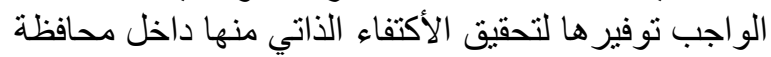

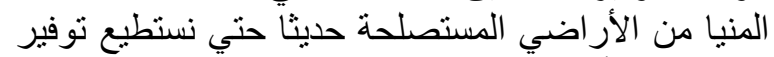

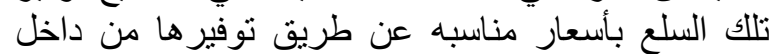
المحافظة وتوفير تكاليف النقل. ثانيا: تبني سياسة تخفيض تهريض

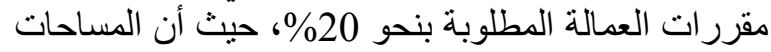

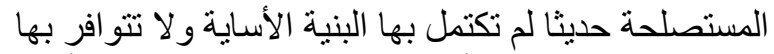

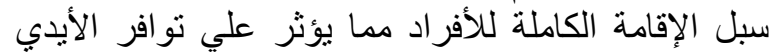

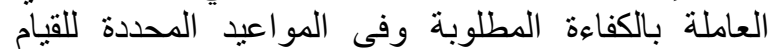

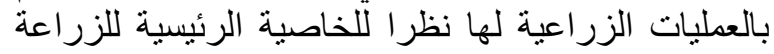

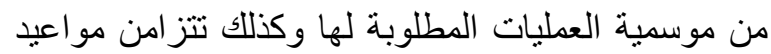

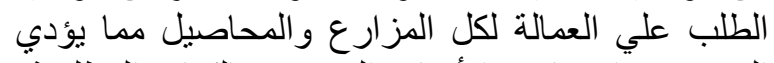

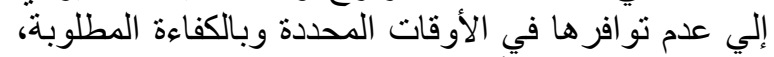

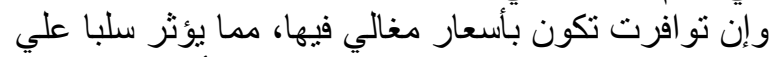

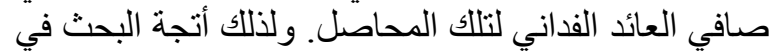
هذا السيناريو نحو توفير 20\% من العمالة البشرية مقابل

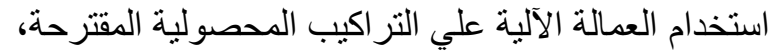

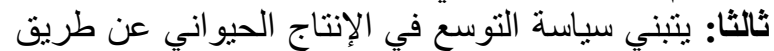

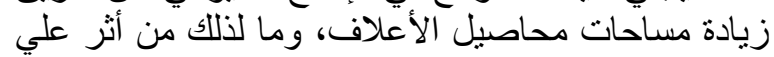

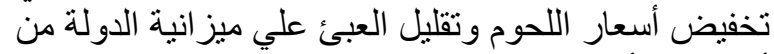

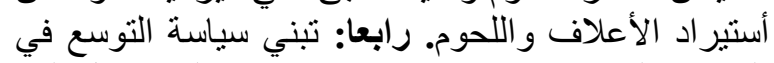

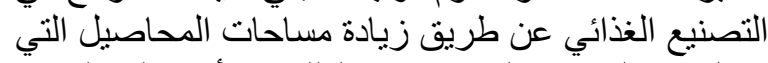
تدخل في التصنيع الغذائي، وما لذلك من أثر علي التوسع التي
5. 2. 1. التركيب المحصولي المقترح للمحافظة محل

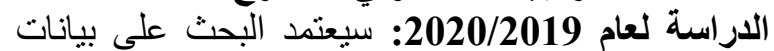
التراكيب المحصولي المنشوره لتلاك المحافظة لآخر ثلاثة

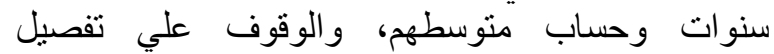
الرحاصيل التي يتضمنها كلا من التراكيب التحصصولية

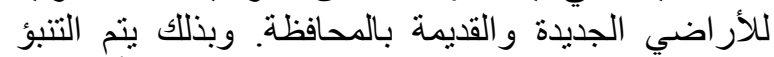

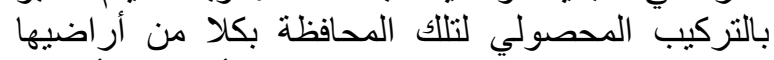
القديمة والجديدة لعام 2020/2019 بأستخدام أسلوب الألي برمجة الأهداف لتدنية الأحتياجات من موردي العمالة و المياه.

5. 2. 2. التركيب المحصولي المقترح للمحافظة محل الزئل الاراسة لعام 2025: يؤخذ في الإعتبار الفترة الزئرة الزمنية

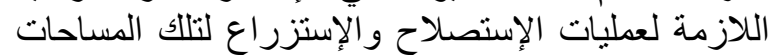

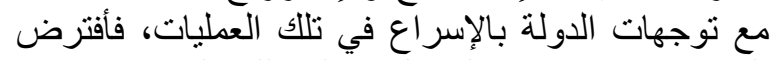

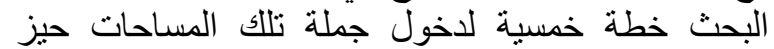
الإنتاج، أب أن التراكيب المحصولية المقترحة تكون لعام لعات

ولهذا تم حساب ما يخص تلك المحافظة من المليون و

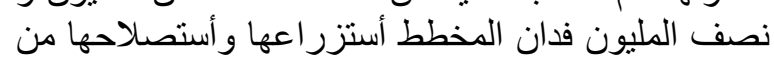

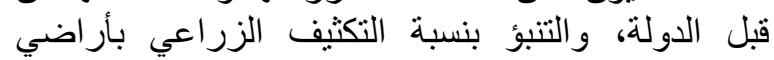

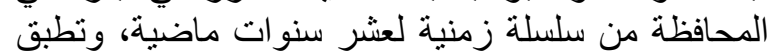

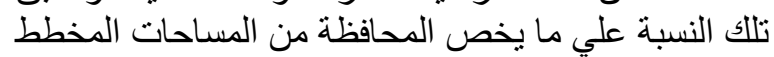

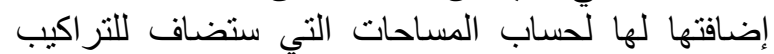

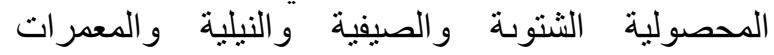

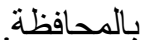
ولكن نظرا لأنه بعد إلغاء التخطيط الإجباري أصبح

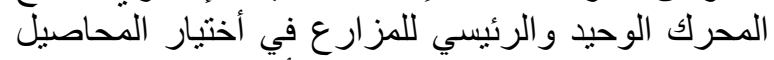

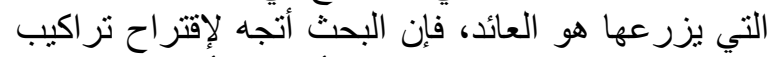

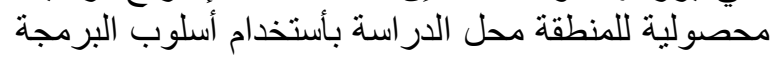

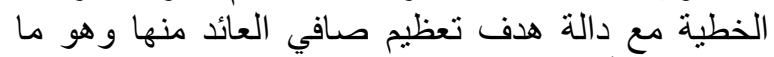
يتمشي مع أهداف المزار عيين، ولكن نظئ نظرا لعدم إمكانية

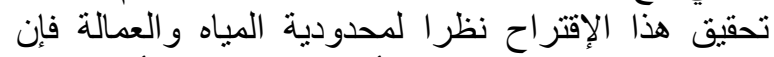

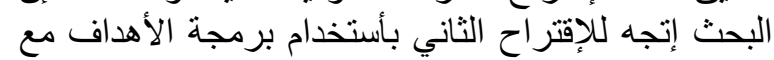

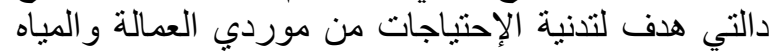

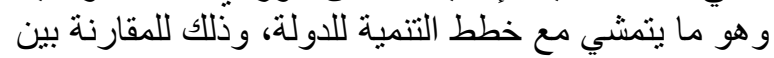
عوايد كلا منهم ومقارنتها بالاحتباجات المائية والعمالة، لإلة الإنة وصو لا لأختيار أنسبها لتطبيق سياسات الدانيات الدانية الإنتاجية

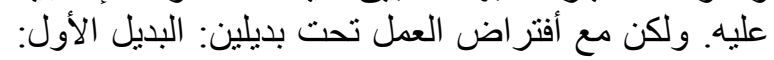

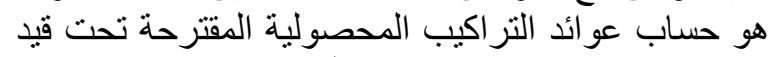
إنتاجية فدانية 50\% للفدان للأراضي الجدية الجديدة، البديل

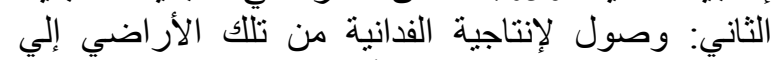

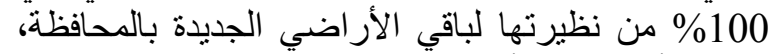

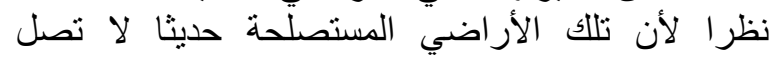
للإنتاجية الحدية إلا بعد فترة زمنية من الأخول في عملية لإنية الإنتاج.

5. 2. 3. السياسات الإنتاجية المقترح تطبيقها على

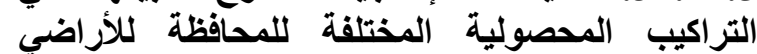

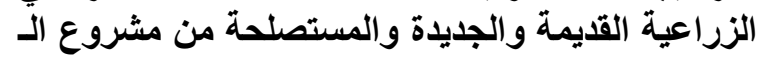

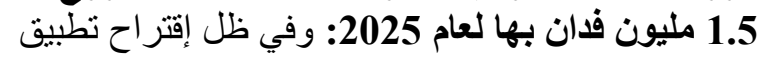
بعض السياسات الإنتاجية علي تللك المساحات المضافة 


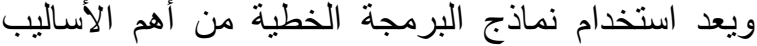

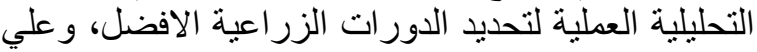

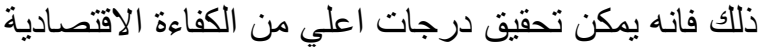

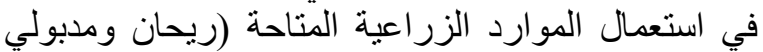
1975). وتعتبر البرمجة الخطية من بين الاساليب التحليلية التي تستخدم عادة لحل المشاكل المتضمنة ملنة علاقات دالية خطية لعديد من المتغيرات بهدف عادة معظمة او تدنية دالة التهات

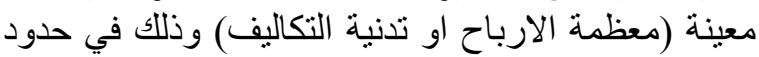

القيود او المحددات المختلفة التي يمكن صياغتها لأنها جبريا. الفروض الواجب توافرها لاستخدام النماذج الرياضية للبرمجة الخطية سالي بوادي (2006)، هي تحديد جيد لدالة الهدف، تعدد بدائل تحقيق الهدف، خطية دالة الهرف الته

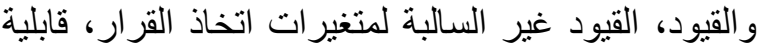
التجزئة للموارد والانشطة، تناسب مستوى الانشطة مع

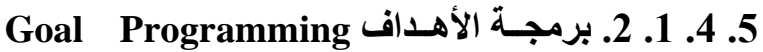
برمجة الأهداف هي إمتداد للبرمجة الخطية الخدية، حيث تعتمد

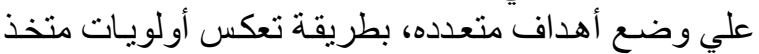

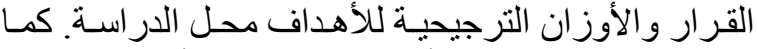

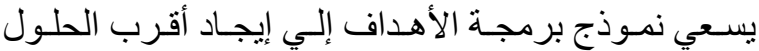

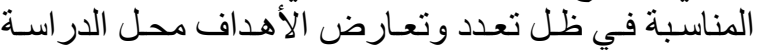

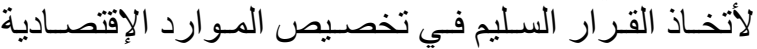

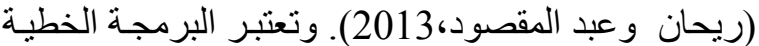

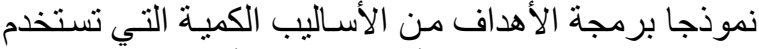

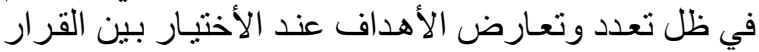

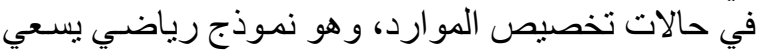
إلي إيجاد أقرب و أحسن الحلول إلي القيم المحددة للأهداف.

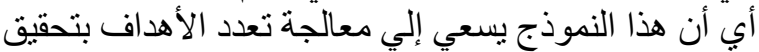

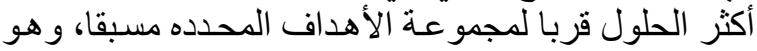

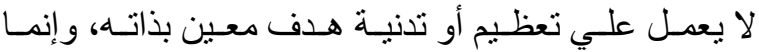

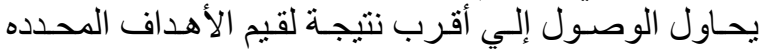

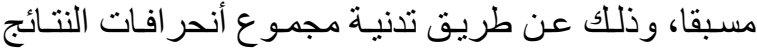

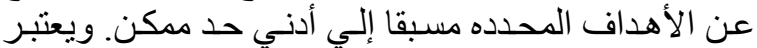

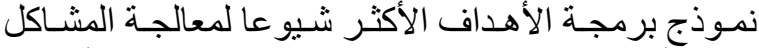

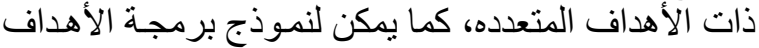

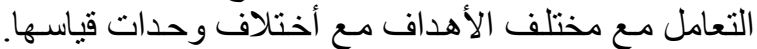

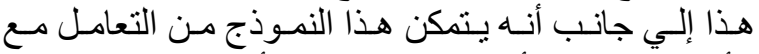

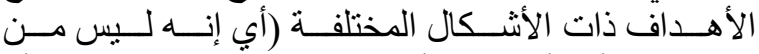

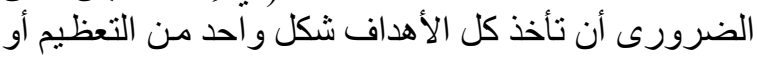

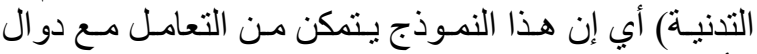

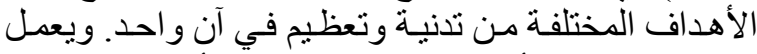

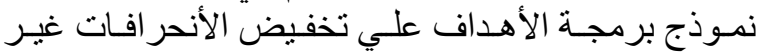

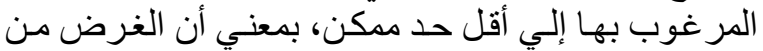

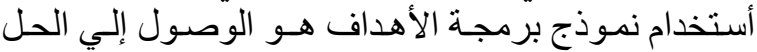

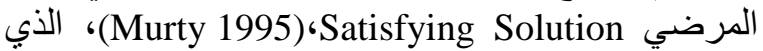
يخفض مجمـوع الأنحر افـات عـن الأهداف المرجـوة إلـي

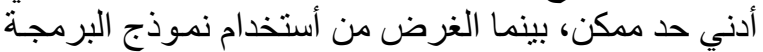

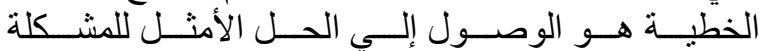

(Optimized Solution)
في إنتاج تلك المحاصيل التي يصعب تسويقها طازجة

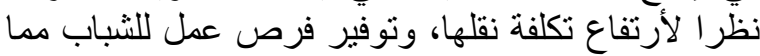

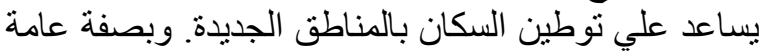

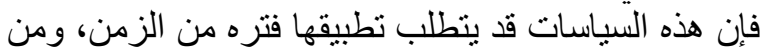
ثم فهي سباسات مناسبة في المدي الطويل. 5. 3. مصادر البيانـات مئات

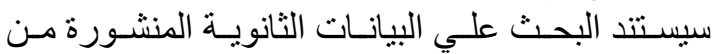

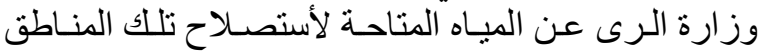

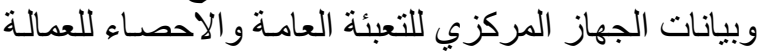

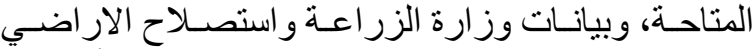

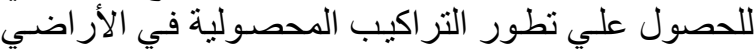

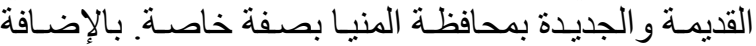

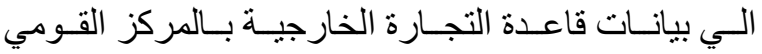

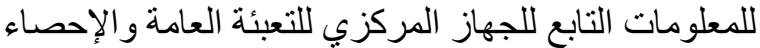

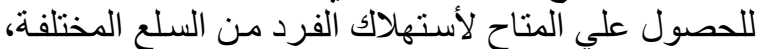

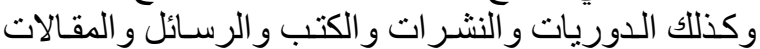

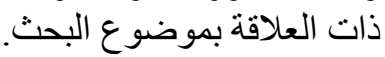

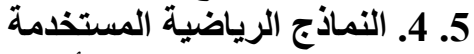

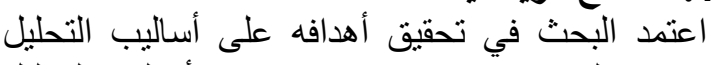
الإحصائي الوصفي، كما تم استخدام بعض أساليب التحليل

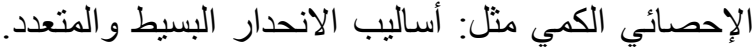

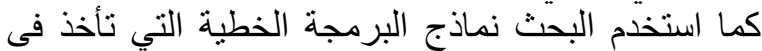

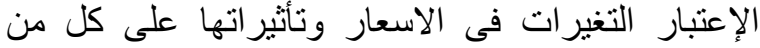

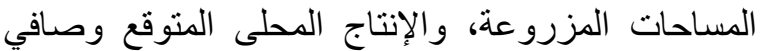

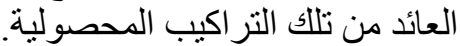

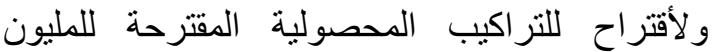
ونصف فدان المقترح أستصلاحها وفقا للمراحل الثناثة

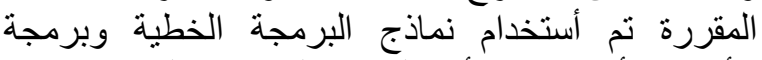
الأهداف بأعتباهم من أهم النماذج الرياضية المستخدمة في

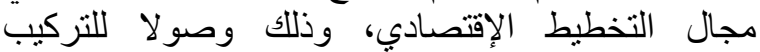
المحصولي الأفضل من أستخدام العمالة والمياه المتاحة و المحدوده ونتائج تبني السياسات الزر اعية المختلفة محل

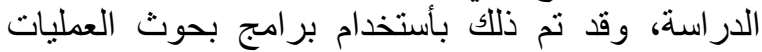
بصفة عامة مثل برنامج Lindo. هذا وقد أتفقت جميع النماذج المستخدمة للبرمجة (البرمجة الخطية ولمدة وبرمجة الأهداف) في كلا من الأنشطة الزراعية والقيود، ورلكنها أختلفت في دوال الأهداف في كن. الأ الأن.

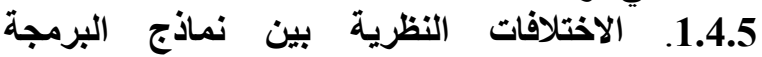
المستخدمة (البرمجة الخطية وبرمجة الأهداف)

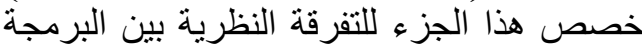

$$
\text { الخطية وبر مجة الأهداف نظريا. }
$$

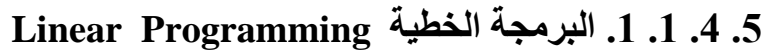
تعتبر البرمجة الخطية من أكبر إنجاز ات منتصف التهن القرن

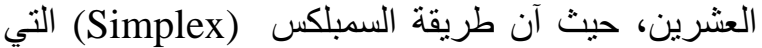

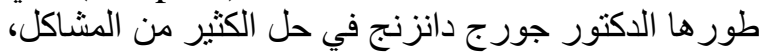

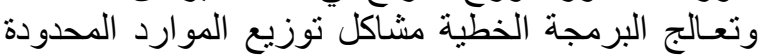

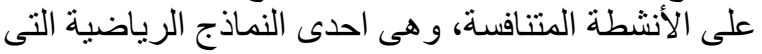

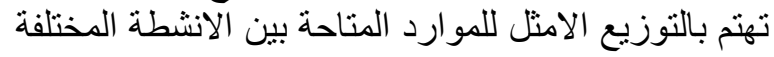
بهدف تحقيق اقصى كفاءة انتاجية و اقتصادية من استخدام

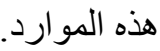


الأهداف المتوقعة من التركيب المحصولي المقترح هي:

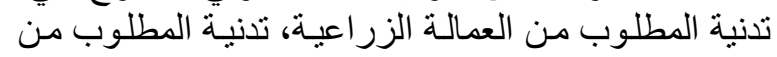

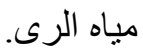
5.5. 4. 2. 3. 3. قيود نموذج البرمجة الخطية

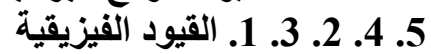

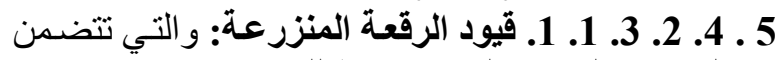

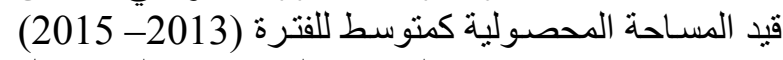

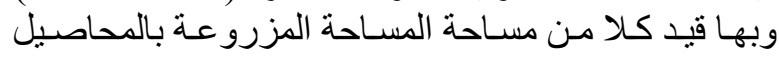

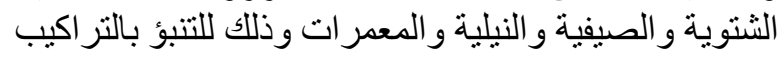
المحصولية المتوقعة لعام 2019.

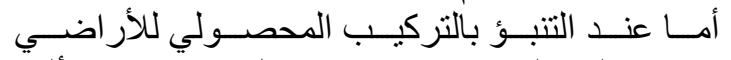

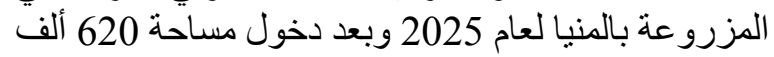

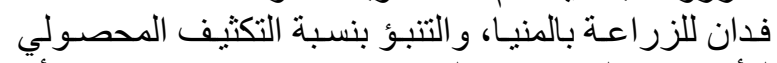

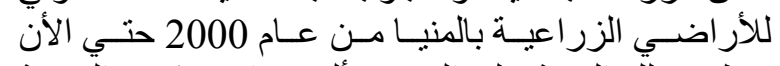

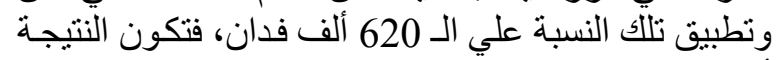

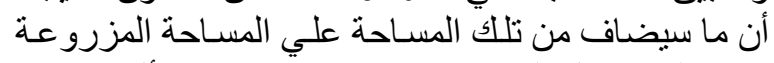

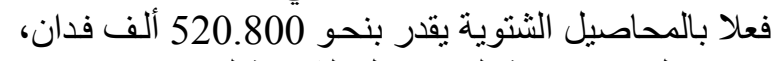
مما يجعل قيد مساحة المحاصيل الثنتوية لعام 2025 يقدان يقدر

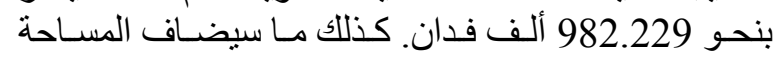
المزرو عة فعلا بالمحاصيل الصيفية يقدر بنحو 502.200

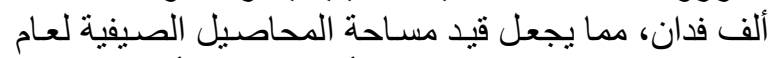

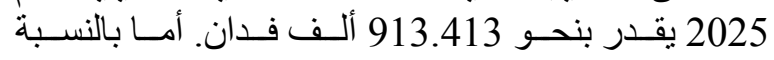

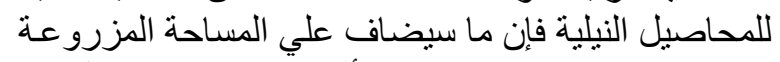

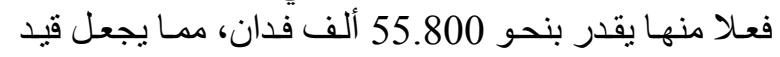

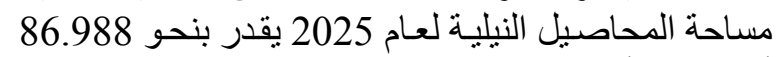

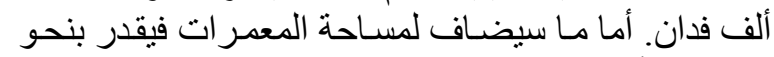

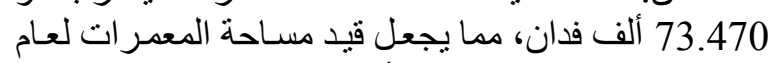
2025 يقدر بنحو 115.226 الف 1157 ألف فدان. 5. 4. 2. 3. 1. 2025 بـ 2. قيود الموارد المائية

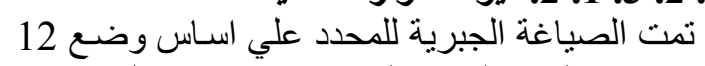

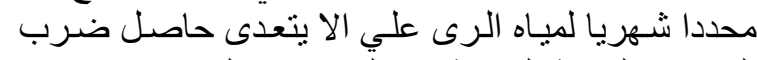

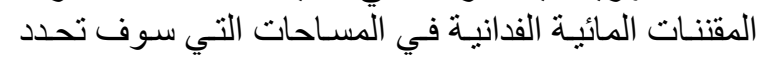
داخليا بالنموذج عن اجمالي كمية المياه المتاحة في الثهر الثر موضع الإعتبار.

5. 4. 2. 3. 1. 1. 3. 3. قيود العمالة الزراعية

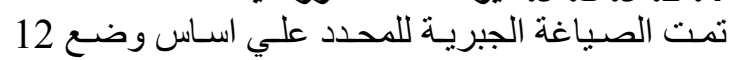

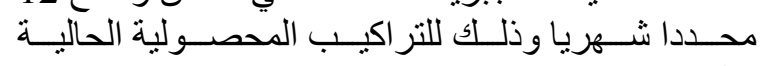

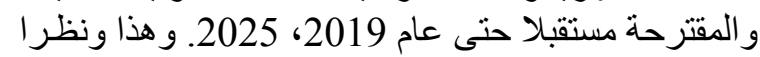

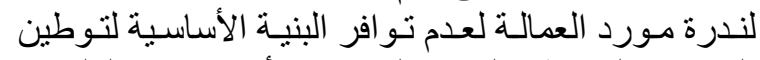

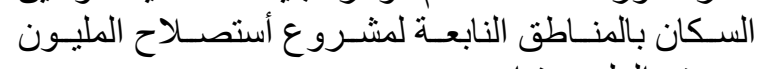

$$
\text { ونصف المليون فدان. }
$$

5.5. 4. 2. 3. 3. 2. 2. 2. 1انقيود التظيمية

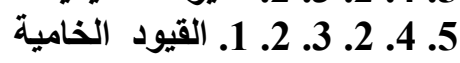

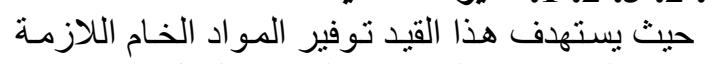

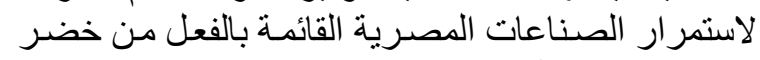

$$
\text { وفاكهاه وقصب السكر. }
$$

5. 4. 2. 3. 2. 2. 2. قيود تسويقية

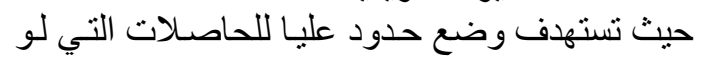

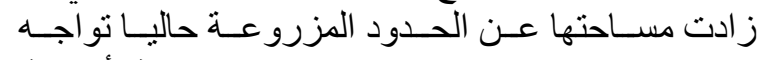

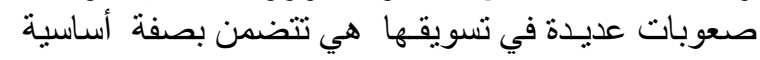

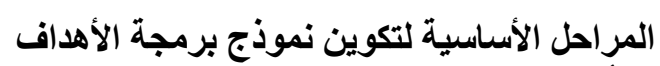

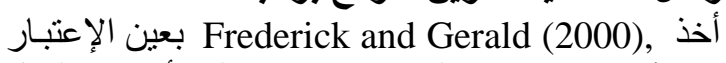

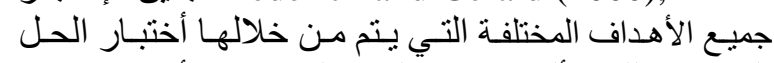

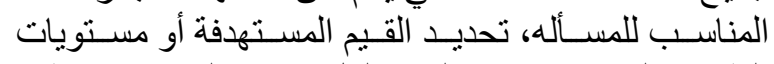

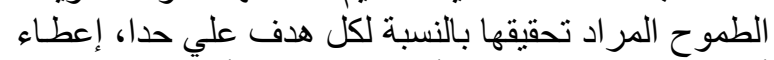

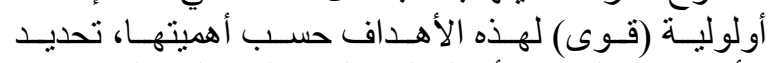

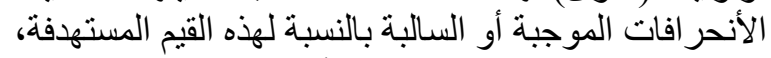

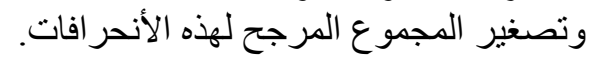

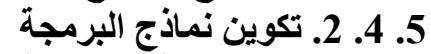

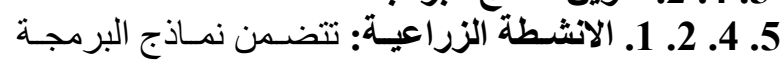

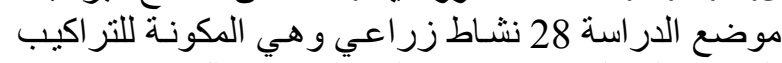

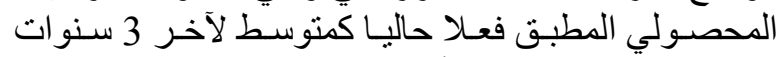

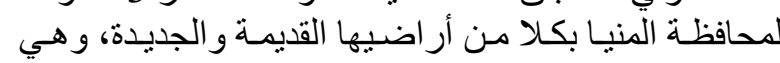

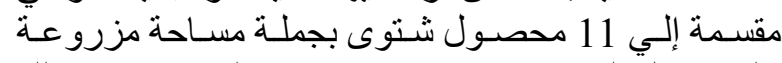

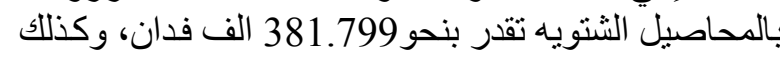

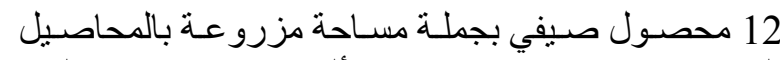

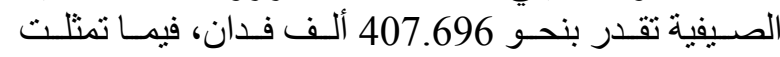

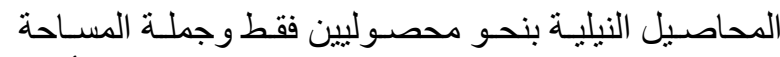

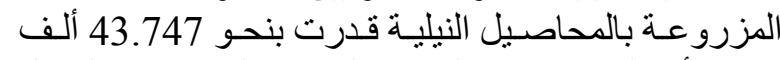

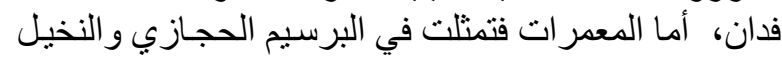

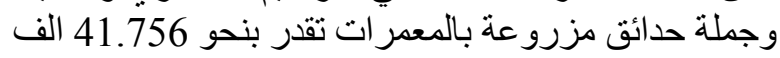

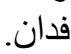

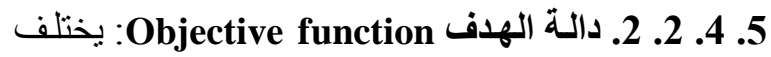

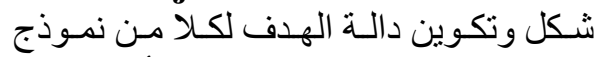

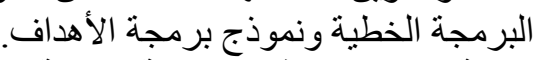

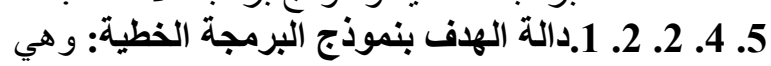
تتمثل في معظمة صـافي العائد من الانشيطة الخطية

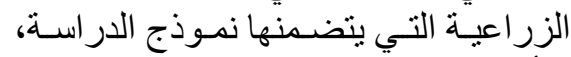
وتأخذ دالة الهذف الثكل التالي:

MAX Y $=\mathrm{N}_{1} * X_{1}+\mathrm{N}_{2} * \mathrm{X}_{2}+\ldots \ldots .+\mathrm{N}_{\mathrm{n}} * \mathrm{X}_{\mathrm{n}}$.

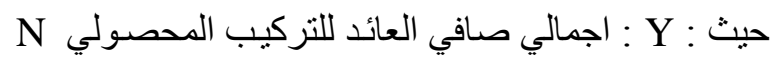

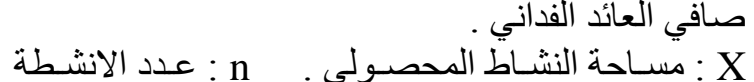

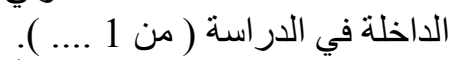

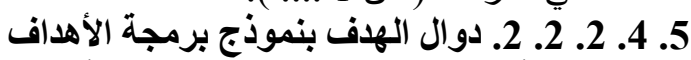

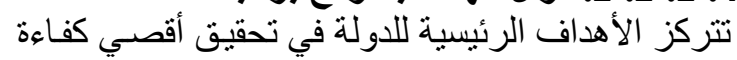

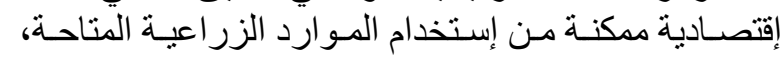

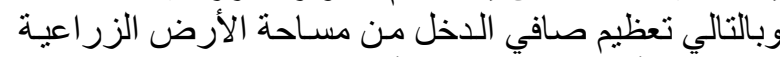

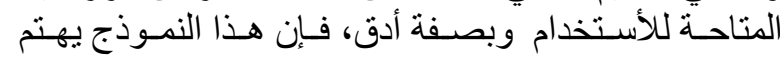

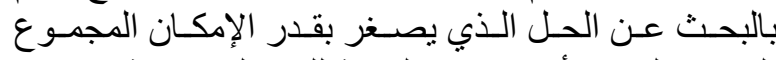

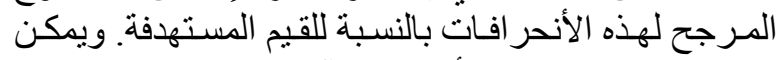
صياغة نموذج برمجة الأهداف كالآتي: $\operatorname{Min} Z=\sum^{{ }^{p}}{ }_{i=1}=\left(\delta^{+}{ }_{i} \delta^{-}{ }_{i}\right)$

$\sum \mathrm{aijxi}-\delta^{+}{ }_{\mathrm{i}}+\delta^{-}{ }_{\mathrm{i}}=\mathrm{gi}$

$\mathrm{cx} \leq \mathrm{C}$

$\mathrm{Xi} \geq 0(\mathrm{j}=1,2, \ldots . \mathrm{n})$

$\delta^{+}$et $\delta^{-} \geq 0(\mathrm{i}=1,2,3, \ldots . . \mathrm{p})$

وييحث نموذج البرمجة متعدد الأهداف عن مجموعة المعة الحلول الكفء داخل منطقة الحل المكن. 
المقرر دخولها العملية الإنتاجية في الفترات القادمسه وحتي

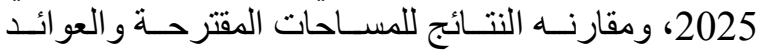

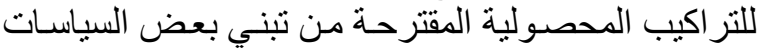

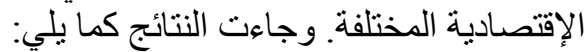
1.6. متوسط التركيب المحصولي الحالي السائد للأراضي اضلي الزئ الزراعية بمحافظة المنيا

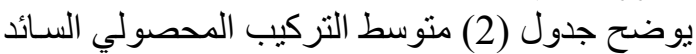

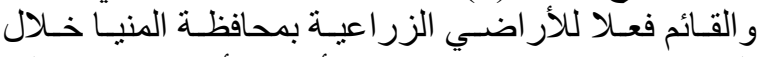

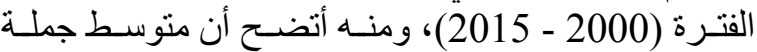

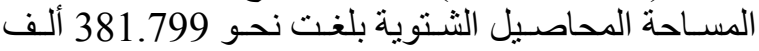

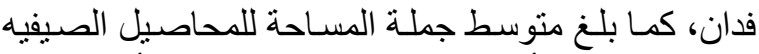
نحـو 407.696 ألـف فـدان، وكذللك 43.747 ألـف فـدان للمحاصـيل النيليـة. وبـللك وبعـد إضـافة متوسط وسط مسـاحات

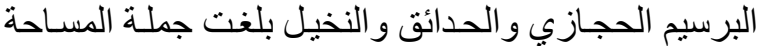

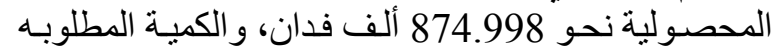

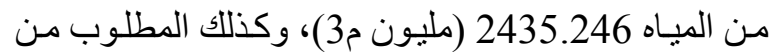
العمالة 58.376 (مليون يوم عمل)، وصافي العائد 5.558 وليون

(مليار جنية).
الخضرو ات الثنتوية و الصيفية.

5. 4. 3. 3. 3. قيود اخرى اقتصادية محلية و عالمية التية

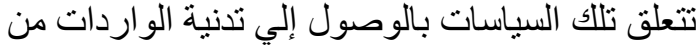

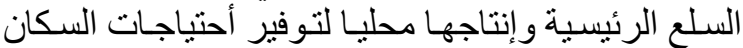

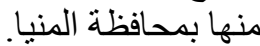

\section{6. نتائج البحث ومناقشتها}

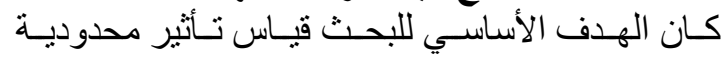

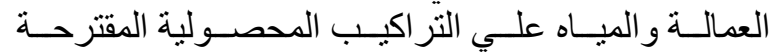

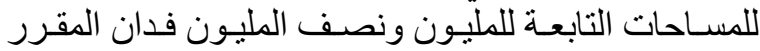

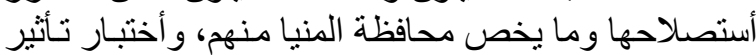

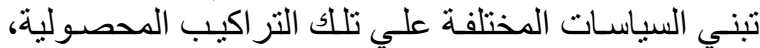

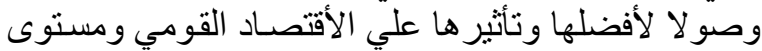

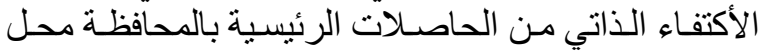
الدر اسة.

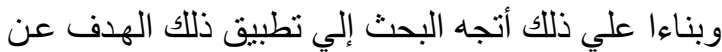

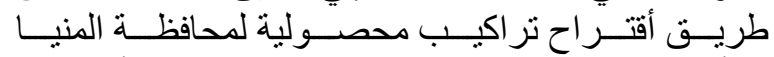

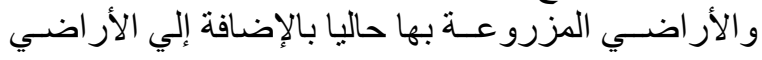

جدول رقم (2): التركيب المحصولي السائد في محافظة المنيا لمتوسط الفترة (2013- 2015) بالفدان.

\begin{tabular}{|c|c|c|c|}
\hline متوسط المساحة & المحصول & متوسط & المحصول \\
\hline 20967 & فــول الصــويا (ص) & 87012 & البرسـيم (المستديم+ التحريش) (ش) \\
\hline 1679 & عبـاد الثـــس (ص) & 236000 & القمــــــ (ش) \\
\hline 6251 & البطـــاطـــس (ص) & 478 & الثـــــير (ش) \\
\hline 6546 & الطمــــاطـــم (ص) & 242 & الفول البلدى (ش) \\
\hline 13201 & الخضروات الأخرى (ص) & 3756 & البصـــــل (ش) (ش) \\
\hline 3753 & المحاصيل الأخرى (ص) & 5128 & الثــــــــ (ش) \\
\hline 353 & ـن (ص) & 22859 & بنجـر السـكر (ش) \\
\hline 36980 & القصــــــــب & 8285 & الطماطم (ش) \\
\hline 407696 & جملة المحاصيل الصيفية & 2826 & اخري (ش) \\
\hline 6967 & البصــــــــل (ن) & 5054 & الخضروات الأخرى (ش) \\
\hline 36780 & البطـــــــــ (ن) & 10159 & المحاصيل الأخرى (ش) \\
\hline 43747 & جملة المحاصيل النيلية & 381799 & جملة المحاصيل الثتوية \\
\hline 1227 & جملة البرسيم الحجازى & 292649 & الذرة الثـاميـة (ص) \\
\hline 39936 & جملة مسـاحة الحدائق & 11592 & الذرة الرفيعــة (ص) \\
\hline 593 & جملة مساحة النخيل & 8069 & الفـول السودانى (ص) \\
\hline 874998 & إجمالى المساحة المحصولية & 5656 & الســمســم (ص) \\
\hline
\end{tabular}

\begin{tabular}{|c|c|}
\hline 2435.246 & حجم المياه اللازمه للري (مليون م3) \\
\hline 58.376 & حجم العمالة (مليون يوم عمل) \\
\hline 5.558 & صافي العائد (مليار جنية) \\
\hline
\end{tabular}

المصدر: وزارة الزراعة واستصلاح الاراضيـ قطاع الثئون الإقتصاديةـ نشرات الإقتصاد الزراعي. 
وكذلك فإن المحاصيل المقترح زراعتها بتلك الأراضي

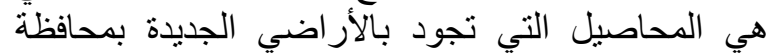

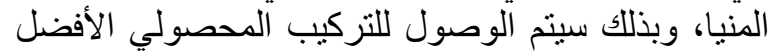
لعام 2025، في ظل قيود كمية المياه والعمالة المتاحة، الإلئ و القيود الخامية التسويقية الأخري. وسيتم ذللك من خلال بديلين، البديل الأول هو إقتر التراح

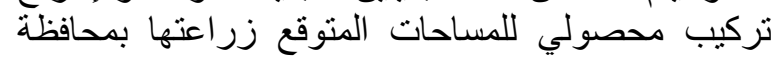
المنيا عام 2025 و المنضمنة المساحات الموجودة الماتيات حاليا

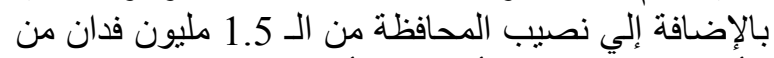

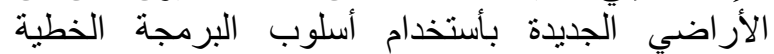

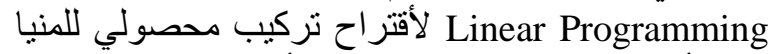

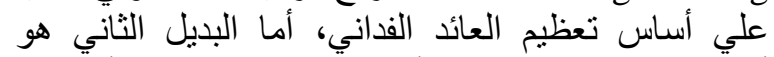
أقتر اح تركيب محصولي لأر اضي محافظة المنيا بأستخدام

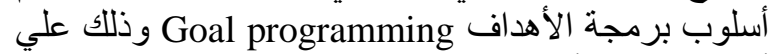
أساس تدنية الأحتياجات من المياه والإن ومن العمالة الزراعية.

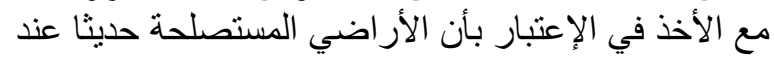

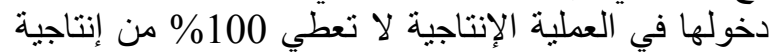

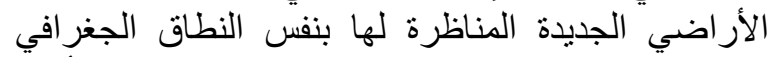
و الظروف المناخية، ولهذا تم العمل تحت فرضئة لكين: الأول:

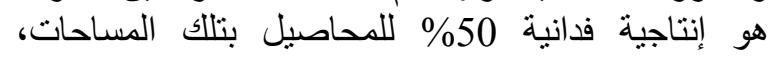
والثاني: عند وصول الإنتاجية الفدانية لتلك المحاصية الماصيل

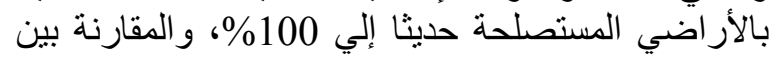
النتائج النهائية لكلا من هذينين الفرضين الفين لكل نركيب محصولي مقترح. جدول (4) يبين أن نتائج التركيب المحصدولي المقترح

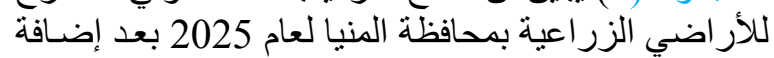

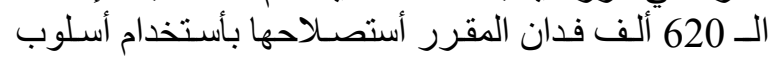

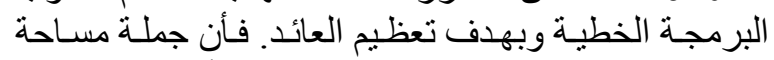
الحاصلات الشتوية ستبلغ نحو 982.229 ألف فعلف فدان، كما

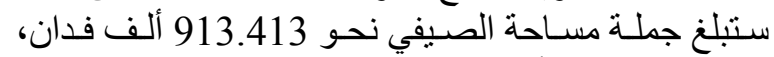
وكذلك 86.988 ألف فدان للّحاصيل النيلية، إلي جانب الئب

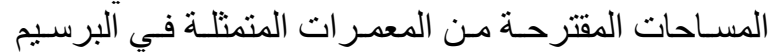

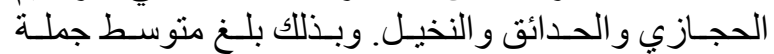

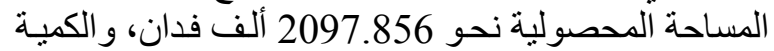

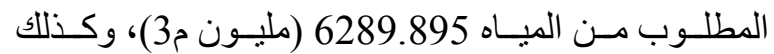

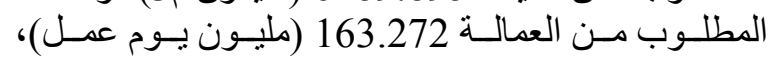

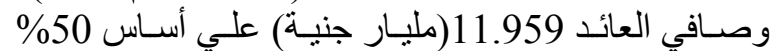
إنتاجية للأر اضي المستصلحة حديثا.

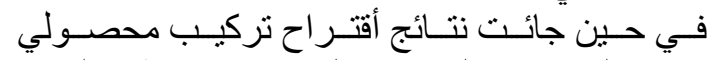

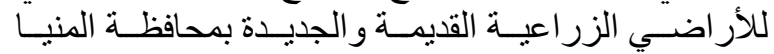

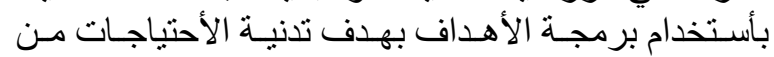

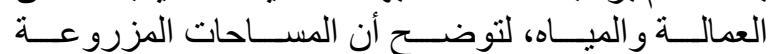

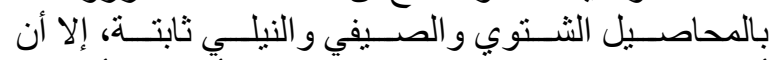

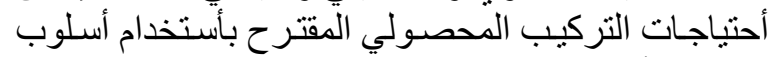

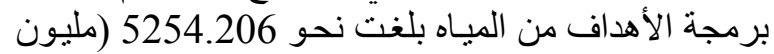

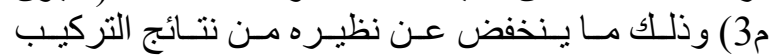
المحصولي المقترح بأستخدام البرمجة الخطية بنحو 16 \%
2.6. المحاصسيل التي تجـود بكـلا مسن الأراضـي القديمسة والجديدة بمحافظة المنيا تبوديا

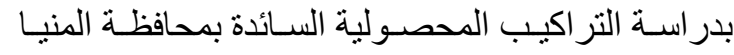
الموضحة بجدول (2) عن التركيب المحصولي السـائد في الفي الفيا

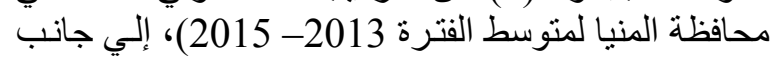
در اسة تفصيل تلك البيانات من مصادر ها المنشورة، بتضح

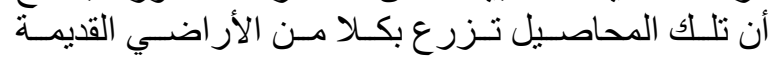

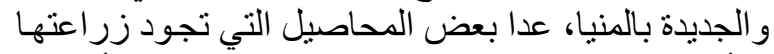

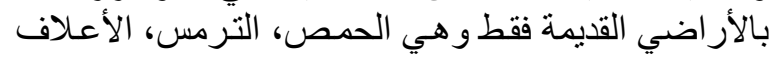

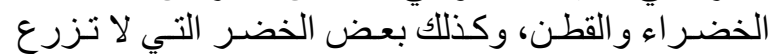

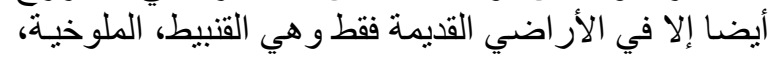

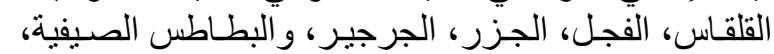

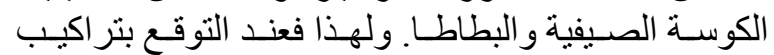
محصولية للأر اضي التابعة لمشروع أستصلاح 1.5 مليون

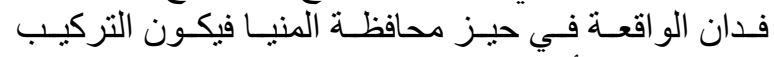

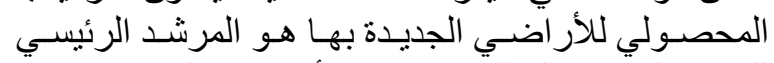

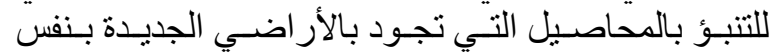
المنطقة ولها نفس الظروف البيئية و المناخية. 6. 3. التركيب المحصولي الأفضل لمحافظة المنيا لعام 2019

ويضم هذا المقترح مختلف المحاصيل الثتوية

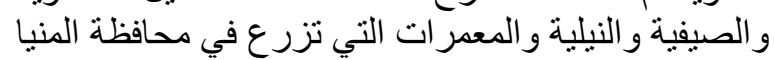

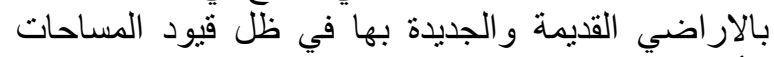

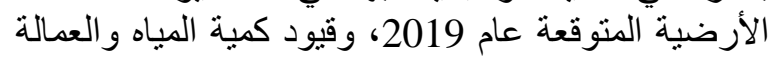

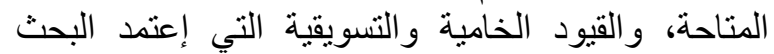
عليها بإستخدام الأتجاه الزمني العام للمساحات المحاتية المحصولية

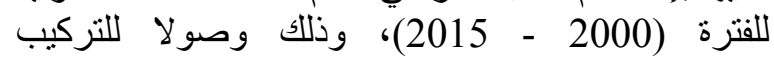

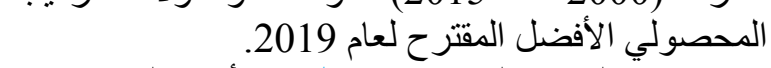

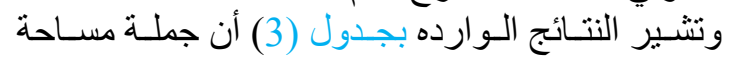

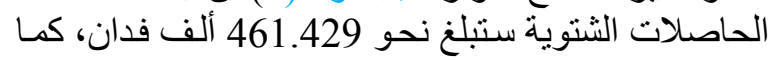

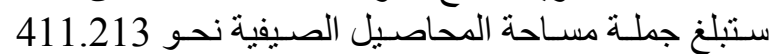
ألف فدان، وكذلك جلك 31.188 ألف فدان للمحاصيل النيلية.

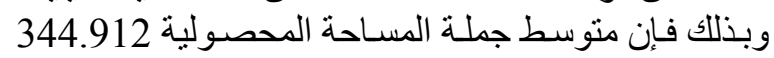

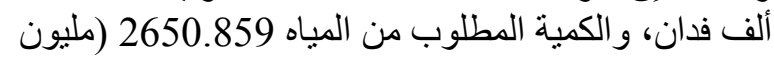

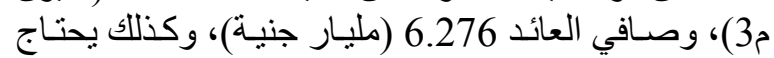

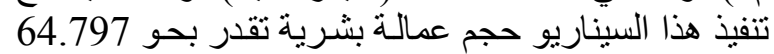

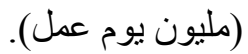

6. 4. التركيب المحصولي الأفضل لمحافظة المنيا لعام 2025

يضم هذا السيناريو مختلف المحاصيل الثنتية

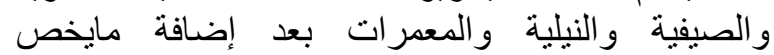

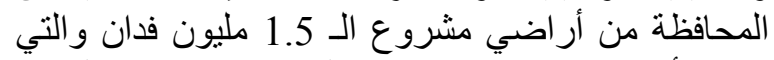

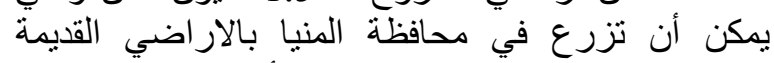

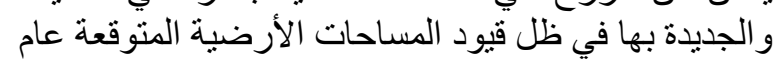

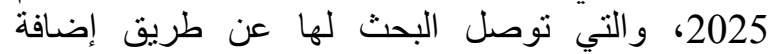

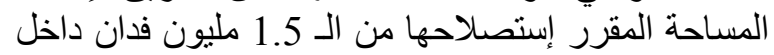

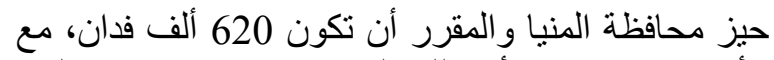

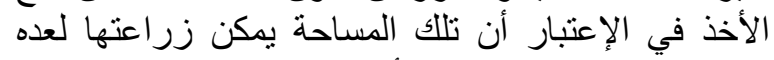

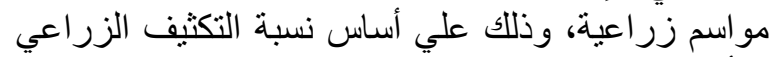
بالأر اضي الجديدة بمحافظةً المنيا للفترة (2000- 2015). 
جدول رقم (3): نتائج التركيب المحصولي المقترح لمحافظة المنيا لعام 2019 بالقدان بإستخدام نموذج برمجة الأهداف.

\begin{tabular}{|c|c|c|c|c|}
\hline التغير \% & \% الفتره من متوسط & $\begin{array}{l}2019 \% \\
\text { من عام }\end{array}$ & متوسط المساحة & المحصول \\
\hline $15+$ & 115 & 21.69 & 100064 & البرســــيم (المستـيم+التحريش) (ش) \\
\hline $13+$ & 113 & 57.89 & 167105 & 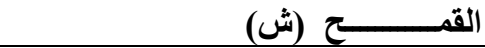 \\
\hline $52+$ & 152 & 0.16 & 725 & الشــــــــــير (ش) (ش) \\
\hline $29+$ & 129 & 0.07 & 313 & الفـول البلدى (ش) \\
\hline $18+$ & 118 & 0.96 & 4434 & البصـــــــــلـ (ش) \\
\hline $19+$ & 119 & 1.33 & 6127 & 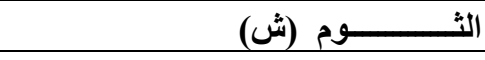 \\
\hline $38+$ & 138 & 6.86 & 31638 & بنجـر الســكر (ش) \\
\hline $11+$ & 111 & 2.00 & 9228 & الطماطم (ش) \\
\hline $668+$ & 768 & 4.70 & 121700 & اخري (ش) \\
\hline $21+$ & 121 & 1.32 & 6112 & الخضروات الأخرى (ش) \\
\hline $28+$ & 138 & 3.03 & 13983 & المحاصـيل الأخرى (ش) \\
\hline $21+$ & 121 & 100.00 & 461429 & جملة مساحة المحاصيل الشتوية \\
\hline $\mathbf{0}$ & 100 & 71.29 & 293139 & الأرة الشــاميــة (ص) \\
\hline $3+$ & 103 & 2.90 & 11942 & الأرة الرفيعــــــة (ص) \\
\hline $4+$ & 104 & 2.05 & 8419 & الفــول السـودانى (ص) \\
\hline $6+$ & 106 & 1.46 & 6006 & 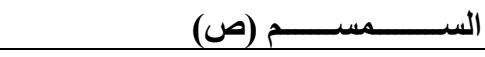 \\
\hline $2+$ & 102 & 5.18 & 21317 & فـــول الصـــــويا (ص) \\
\hline $8+$ & 108 & 0.44 & 1806 & عبــاد الثــــــسـ (ص) \\
\hline $6+$ & 106 & 1.61 & 6601 & 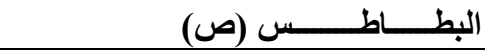 \\
\hline $5+$ & 105 & 1.68 & 6896 & الطمــــــــاطـــــــم (ص) \\
\hline $3+$ & 103 & 3.30 & 13551 & الخضروات الأخرى (ص) \\
\hline $9+$ & 109 & 1.00 & 4103 & المحاصيل الأخرى (ص) \\
\hline $14+$ & 114 & $\mathbf{0 . 1 0}$ & 403 & ــن (ص) \\
\hline $\mathbf{0}$ & 100 & 9.01 & 37030 & 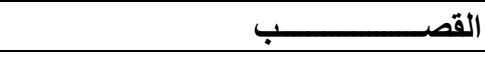 \\
\hline $1+$ & 101 & 100.00 & 411213 & جملة مساحة المحاصيل الصيفية \\
\hline $44-$ & 66 & 14.64 & 4567 & 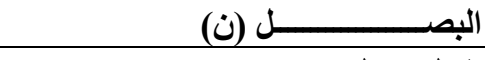 \\
\hline $28-$ & 72 & 85.36 & 26621 & البط البـــــاطـــــس (ن) \\
\hline \multirow[t]{4}{*}{$29-$} & 71 & 100.00 & 31188 & جملة مساحة المحاصيل النيلية \\
\hline & & & 727 & جملة البرسيم الحجازى \\
\hline & & & 14836 & جملة مســاحة الحدائـق \\
\hline & & & 463 & جمـلة مسـاحة النخيل \\
\hline
\end{tabular}

$$
\text { ملخص النتائج }
$$

\begin{tabular}{|c|c|c|c|}
\hline $4+$ & 104 & 912.344 & المساحة المحصولية (الف فدان) \\
\hline $9+$ & 109 & 2650.859 & حجم المياه اللازمه للري (مليون م3) \\
\hline $11+$ & 111 & 64.797 & عمالة (مليون يوم عُمل) \\
\hline $13+$ & 113 & 6.276 & \\
\hline
\end{tabular}


جدول رقم (4): نتائج التركيب المحصولي المقترح لمحافظة المنيا لعام (2025) بالفدان بالبرمجة الخطية وبرمجة الأهداف بعد دخول 620 ألف فدان أراضي جديدة.

\begin{tabular}{|c|c|c|c|c|c|}
\hline \multirow{2}{*}{ نتائج برمحة الأختلاف بلانين } & \multicolumn{2}{|c|}{ برمجة الأهداف } & \multicolumn{2}{|c|}{ البرمجة الخطية } & \multirow[b]{2}{*}{ المحصـول } \\
\hline & 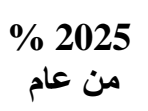 & 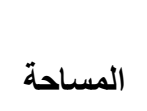 & 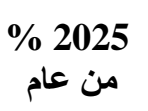 & المساحة & \\
\hline-59 & 10.42 & 102354 & 25.67 & 252180 & البرســــم (مستـيم+تحريش) (ش) \\
\hline 59 & 60.45 & 593710 & 38.09 & 374119 & 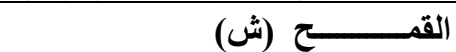 \\
\hline 85 & 0.22 & 2180 & 0.12 & 1177 & الثـــــــعير (ش) \\
\hline 102 & 0.10 & 970 & 0.05 & 481 & الفول البلاى (ش) \\
\hline-40 & 0.79 & 7769 & 1.31 & 12876 & البصــــــــلـ (ش) \\
\hline-34 & 1.14 & 11200 & 1.73 & 16992 & 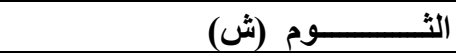 \\
\hline 54 & 9.01 & 88520 & 5.86 & 57516 & بنجــر الســـكر (ش) \\
\hline 32 & 1.83 & 18000 & 1.39 & 13682 & الطماطم (ش) \\
\hline-43 & 12.26 & 120418 & 21.43 & 210521 & اخري (ش) \\
\hline-47 & 0.94 & 9242 & 1.79 & 17534 & خضروات أخرى (ش) \\
\hline \multirow[t]{2}{*}{11} & 2.84 & 27866 & 2.56 & 25151 & محاصسيل أخرى (ش) \\
\hline & 100.00 & 982229 & 100.00 & 982229 & جملة مساحة المحاصيل الثتوية \\
\hline 44 & 77.95 & 712040 & 54.02 & 493450 & الذرة الثــاميـــة (ص) \\
\hline 45 & 3.30 & 30146 & 2.27 & 20720 & الذرة الرفيعــــــة (ص) \\
\hline-72 & 1.52 & 13925 & 5.47 & 49921 & الفــول السـودانى (ص) \\
\hline-17 & 1.09 & 9980 & 1.32 & 12058 & الســـــــــــــــم (ص) \\
\hline-13 & 3.47 & 31654 & 3.97 & 36220 & فـــول الصــــويا (ص) \\
\hline-8 & 0.32 & 2921 & 0.35 & 3186 & عبــاد الثــــــس (ص) \\
\hline 5 & 0.79 & 7230 & 0.76 & 6909 & البطــــــــــــــس (ص) \\
\hline-70 & 1.31 & 11985 & 4.35 & 39721 & الطمـــــــــــــــم (ص) \\
\hline-69 & 2.43 & 22210 & 7.92 & 72325 & خضروات أخرى (ص) \\
\hline-49 & 1.16 & 10582 & 2.26 & 20687 & محاصيل أخرى (ص) \\
\hline 6 & 0.06 & 525 & 0.05 & 495 & 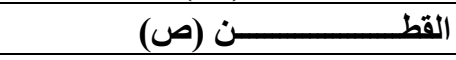 \\
\hline \multirow[t]{2}{*}{-62} & 6.59 & 60215 & 17.27 & 157721 & 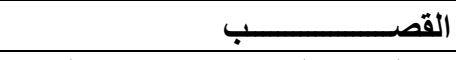 \\
\hline & 100.00 & 913413 & 100.00 & 913413 & جملة مساحة المحاصيل الصيفية \\
\hline-59 & 11.44 & 9954 & 28.04 & 24395 & 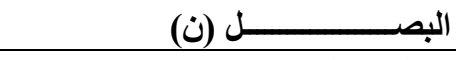 \\
\hline \multirow[t]{2}{*}{23} & 88.56 & 77034 & 71.96 & 62593 & 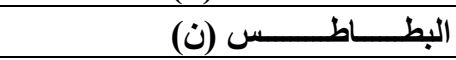 \\
\hline & 100.00 & 86988 & 100.00 & 86988 & جملة مساحة المحاصيل النيلية \\
\hline-40 & & 4627 & & 7738 & جملة البرسيم الحجازى \\
\hline 7 & & 107670 & & 100899 & جملة مســاحة الحدائستق \\
\hline-56 & & 2929 & & 6589 & جمـلة مسـاحة النخيل \\
\hline
\end{tabular}

ملخص النتائج

\begin{tabular}{|c|c|c|c|}
\hline & 2097.856 & 2097.856 & المساحة المحصولية (الف فدان) \\
\hline-17 & 5218.706 & 6254.395 & حجم المياه اللازمه للري (مليون م3) \\
\hline-28 & 116.041 & 160.172 & 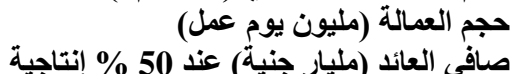 \\
\hline-29 & 7.856 & 10.995 & \\
\hline-29 & 10.475 & 14.660 & للفدان \\
\hline
\end{tabular}




\section{بمحافظة المنيا لعام 2025 في ظل ندرة المتاح من العمالة و المياه}

تم تطبيق هذا السيناريو علي التركيب المحصولي المقترح لعام 2025 للأر اضي الزئريو الاعبة بمحافظة المنيا بأستخدام برمجة الأهداف لأختبار آثار تبني سياسه

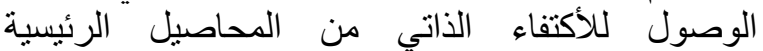

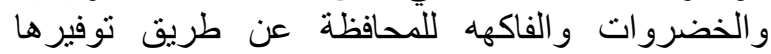

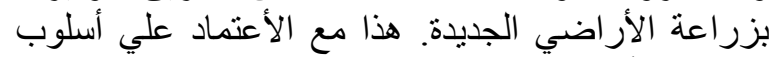

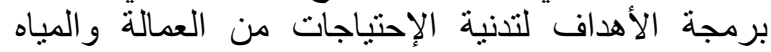

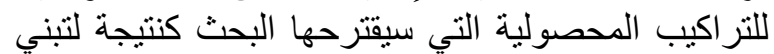

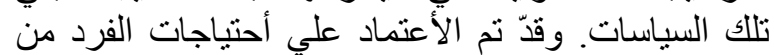

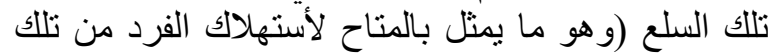

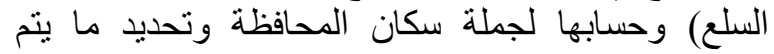
زراعتة من تلك المحاصيل بمحافظة المنيا وتحديد المساحات الواجب توفير ها لتحقيق الأكتفاء الذاتي منها

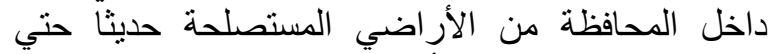

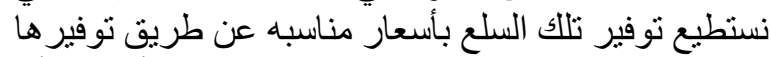

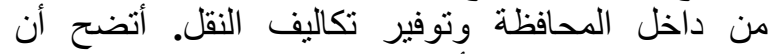
المحاصيل التي تفوق أحتياجات سكان المنيا إنتاج جملة

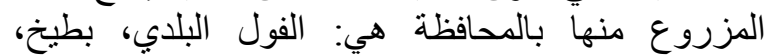

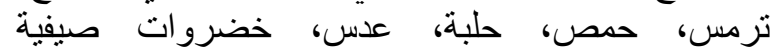
وخضروات شتوية، وقدّ تم مر اعاه حصر محاولة الوصول ترول

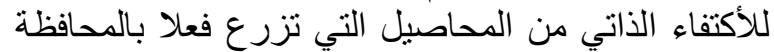
و لا يكفي إنتاجها الأكتفاء الذاتي لسكانها من تلك التئل السلع.

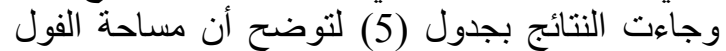
البلدي زادت من نحو 0.970 الف فلف فدان في التركيب

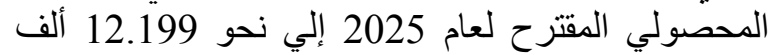

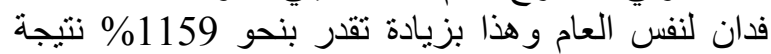
وضع قيد علي مساحة هذا المحصول. كما أرتفعت مساحة الخضروات الأخرى الثنتية و المحاصيل الأخرى الثتنوية

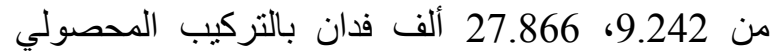

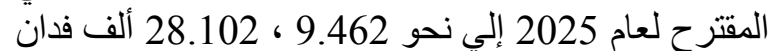

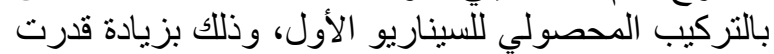

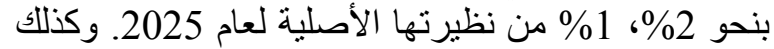

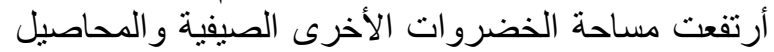

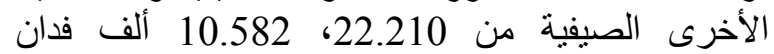

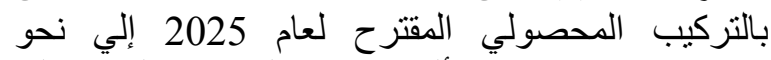

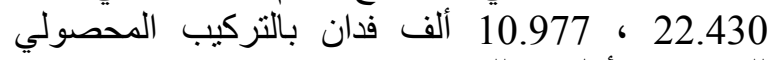

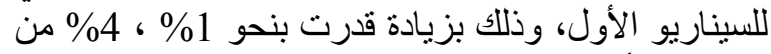

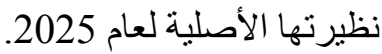
هذا وجاء ملخص النتائج للسيناريو الأول و المتمثلة في لئي

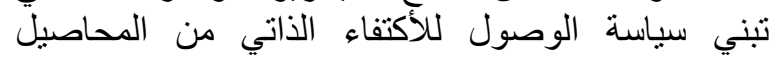

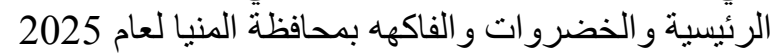

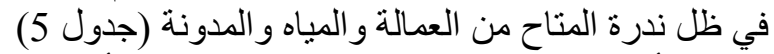

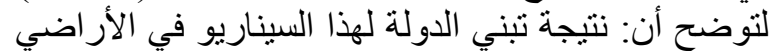

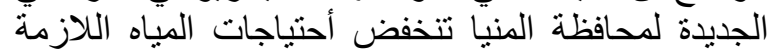

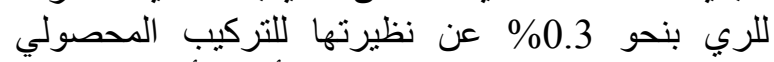

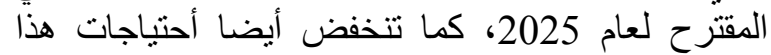

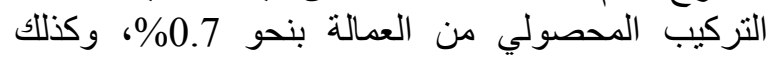
يتناقص صافي العائد نتيجة تبني هذه السياسة بنحو 0.9\%ة
وكذلك جاء المطلوب من العمالة نحو 119.141 (مليون

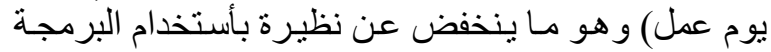

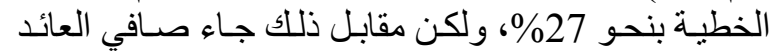

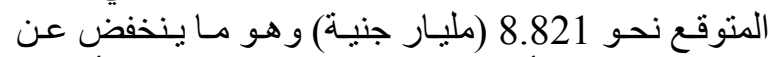

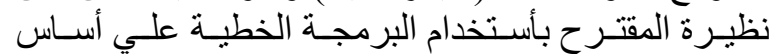

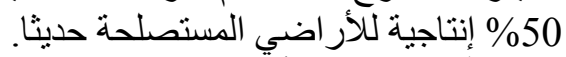

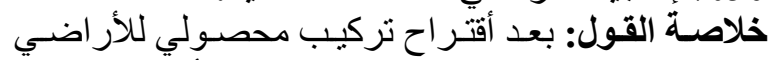

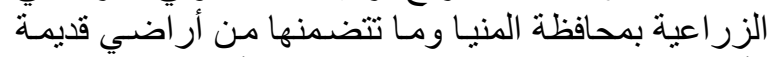

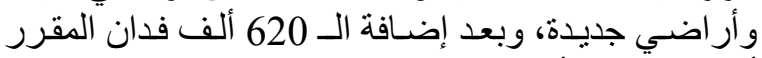

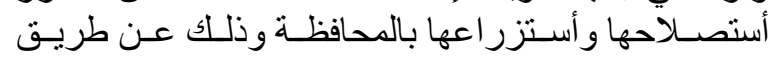

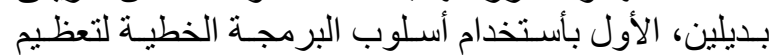

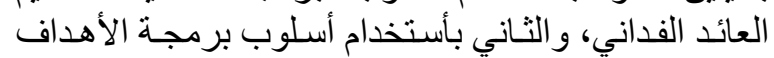

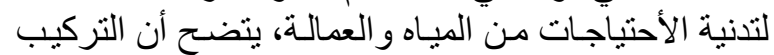

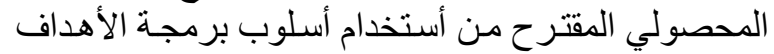

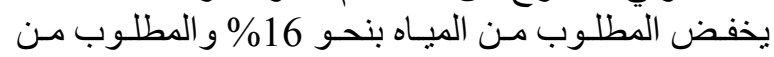

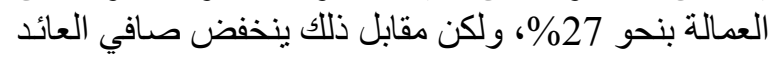

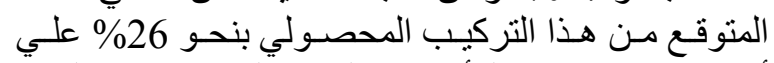

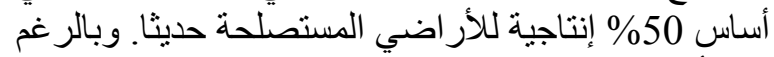

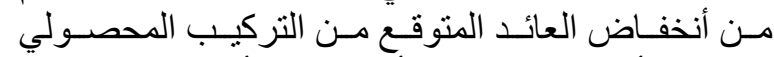

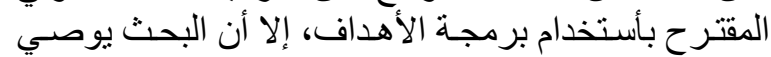

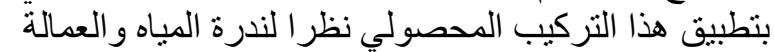

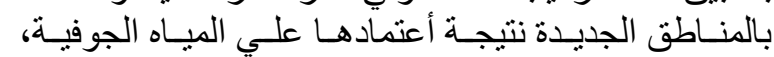

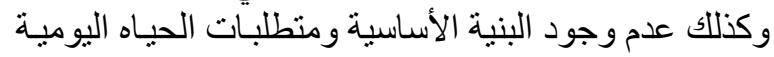

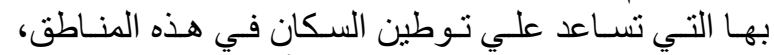
بغض النظر مؤقتا عن تعظيم العائد لأن ذلتك سيكون لفترة فئرة

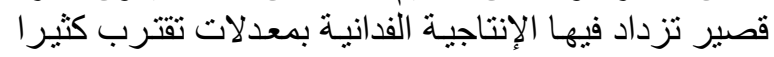

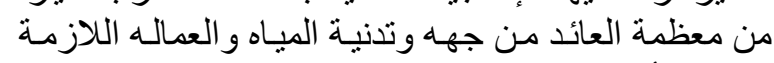
من جهه أخرى. 6. 5. السياسات الإتتاجية المقترح تطبيقها علي التراكيب

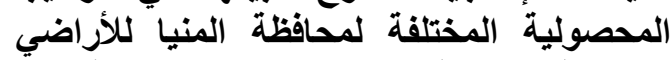

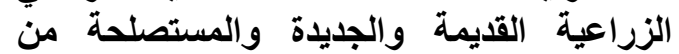

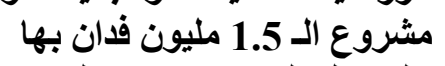

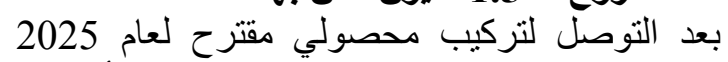

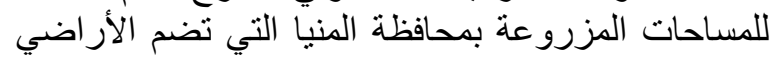

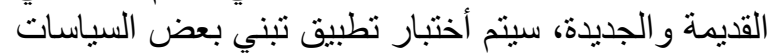

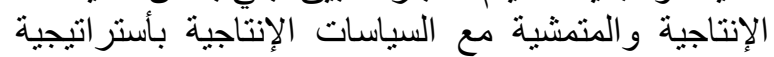

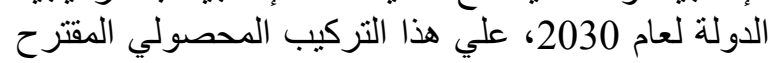

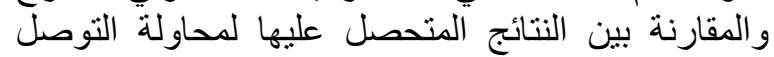
لأفضل تلألك السياسات الإقتصادية ومردودها علي النيات الدولة و الإقتصاد القومي. وكان ذللك من خلال إقتر اح سيناريو هات مختلفة تخدم المباد السياسات المطلوب أختبار نتائج تطبيقها بمحافظة المنيا،

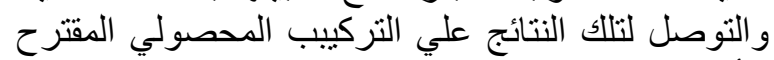

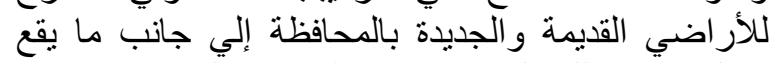

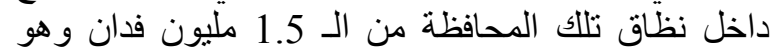

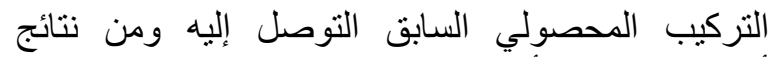
أستخدام برمجة الأهداف: والئي الساءت النتائج كالتنالي: 6. 5. 1. السيناريو الأول: إقتراح تركيب محصولي التئي

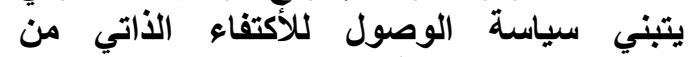

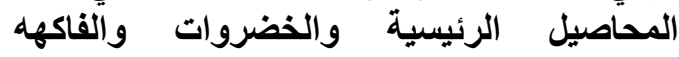


للري بنحو 2025 عن نظيرتها للتركيب المحصولي المقترح

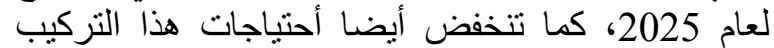

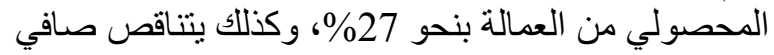

العائد نتيجة تبني هذه السياسة بنحو 0.3\% خلاصة القول: تثشير النتائج إلي أن تبني الدولة النة لسياسة

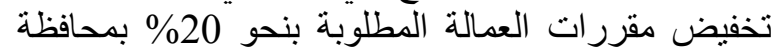

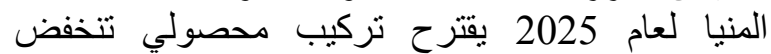

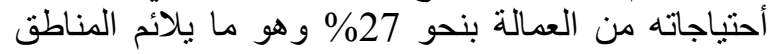
ذات العرض المنخفض من العمالة من العمالة. 6. 3. 3. السيناريو الثالث: إقتراح تركيب محصولي يتبني

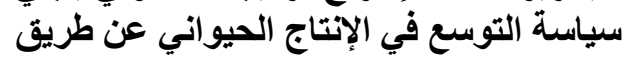
زيادة مساحات محاصيل الأعلاف بمحافئ فئة المنيا لعام 2025 في ظل ندرة المتاح من

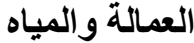

تم تطبيق هذا السيناريو علي التركيب المحصدولي لتئي

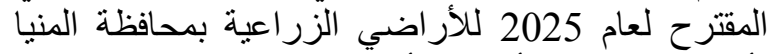

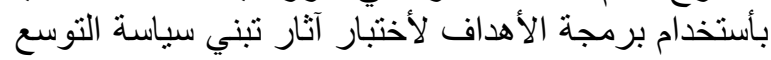
في الإنتاج الحيو اني عن طريق زيادة مساحات محاصيل

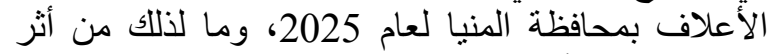

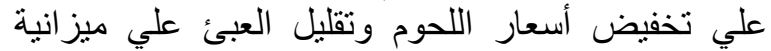

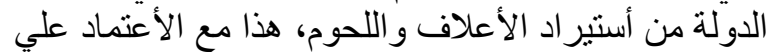

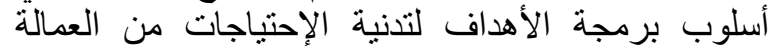
و المياه للتر اكيب المحصولية التي سيقترحها البحث كنتيجة الإنية

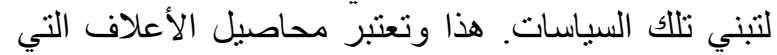
تزرع فعلا بالمحافظة هي البرسيم المستنديم والتئي التحريش

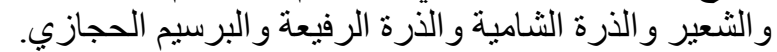

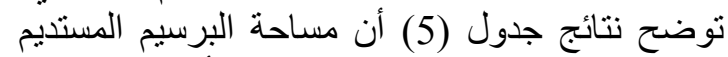

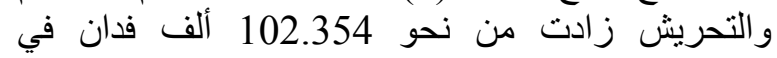

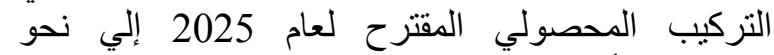
115.159 ألف فدان لنفس العام وهذا بزيادة تقدر بنحو لفير

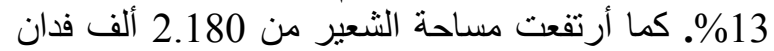
بالتركيب المحصولي المقترح لعام 2025 إلي نحو 2.784 ألف فدان بالتركيب المحصولي للسيناريو الثنالث، وذللك بزيادة قدرت بنحو 28\% من نظئ نظيرتها الأصلية لعام 2025. وكذلك أرتفعت مساحة كلا من الذرة من الذرة الثامية

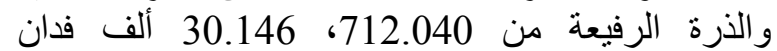

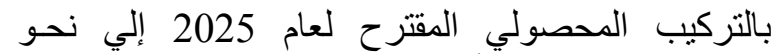

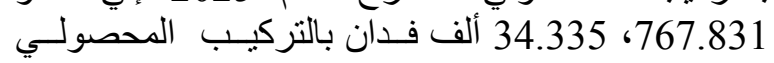

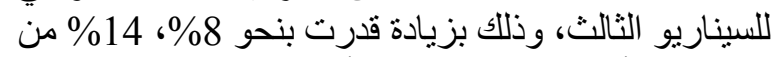

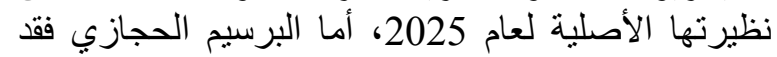

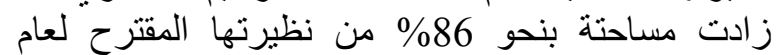
2025

هذا وجاء ملخص النتائج للسيناريو الثالث و المتمثلة في تبني سياسة التوسع في الإنتاج الحيو اني عن طريق لئان زيادة

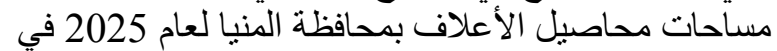
ظل ندرة المتاح من العمالة و المياه، و المدونة (جدول 5 العافي )

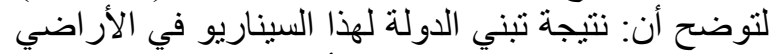

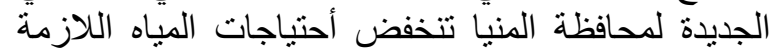

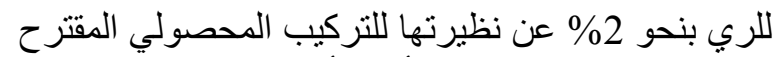

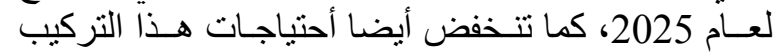

خلاصة القول: تثير النتائج إلي أن ثبني الدولة لسياسة

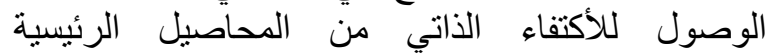

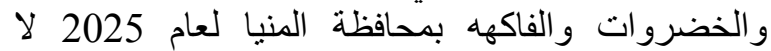
تختلف أحتياجاته النهائية من المياه و العمالة وصافي العائي العائد عن نظيرة المقتر ح لعام 2025. 6. 5. 2. السيناريو الثاني: إقتراح تركيب محصولي مقري يتبني سياسة تخفيض مقربة المطلوبة بنحو 20\% 2025 في ظل ندرة المتاح من العمالة و المياه

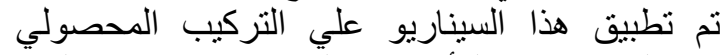

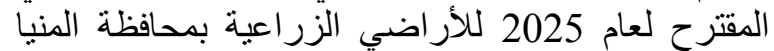

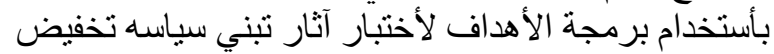

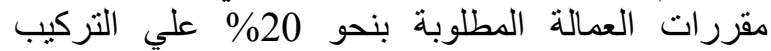

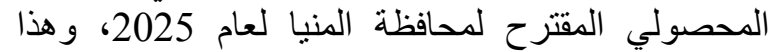
السيناريو يعتمد علي إحلال العمالة الآلية محل العلية العمالة

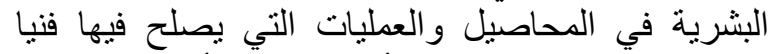

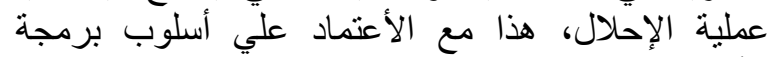
الأهداف لتدنية الإحتياجات من العمالة والمياه للادي للتر اكيب

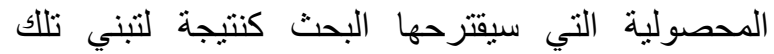

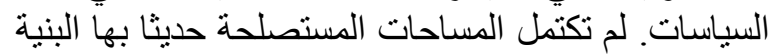

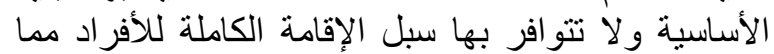

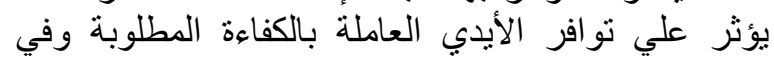

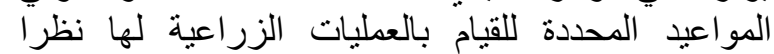

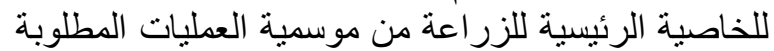

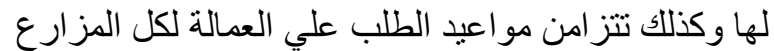

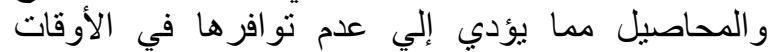

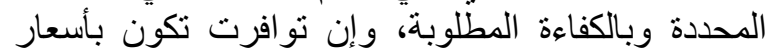

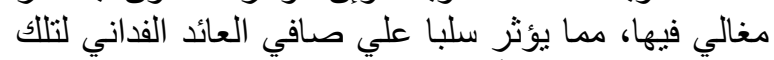

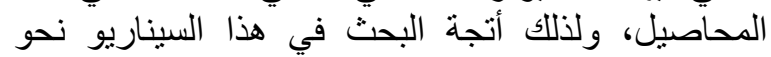

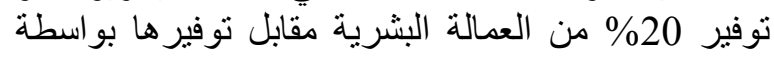

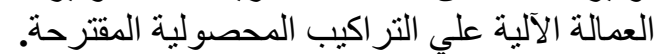
توضح النتائج بالجدول (5) أن مساحة الندائة النحاصيل

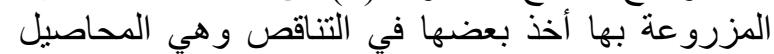

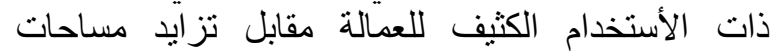
محاصيل أخرى وهي المحاصيل المنذفضضة أستخدام العمالة البشرية. حيث تُخاقصت مساحة البرسيم (المستديم

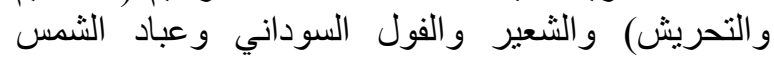

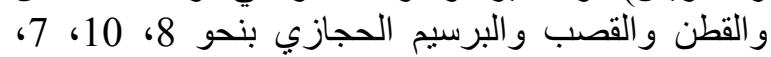

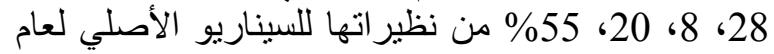

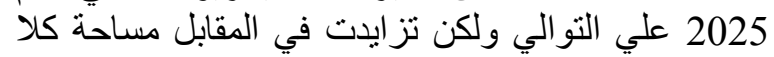

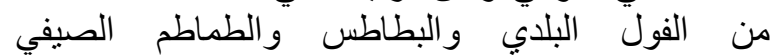

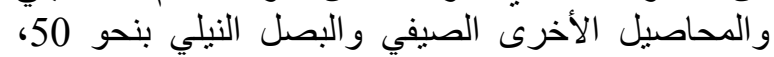
23، 21، 32، 18\% من نظير اتها للسيناريو الأصلي لعام النحي 2025 علي الترتيب.

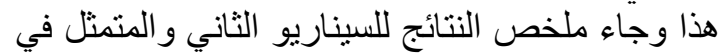

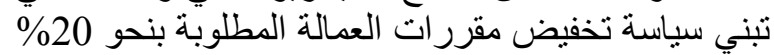

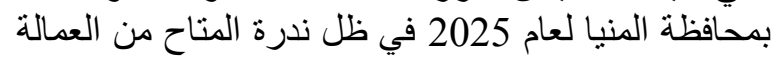

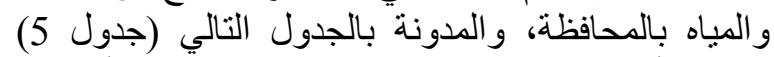

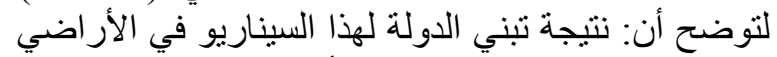
الجديدة لمحافظة المنيا تنخفض أحتياجات المياه اللازمة 
جدول رقم (5): نتائج السيناريوهات المقترحة للتراكيب المحصولية لمحافظة المنيا لعام 2025 بالفدان بإستخدام برمجة الأهداف ـ بعد دخول 620 ألف فدان أراضي جديدة

\begin{tabular}{|c|c|c|c|c|c|c|c|c|c|}
\hline \% لعام من مقترح 2025 & محاصيل التصنئ إنتاج & $\begin{array}{c}\text { مقر م لعام } 2025 \\
2025\end{array}$ & 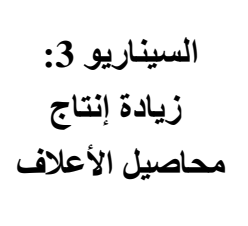 & $\begin{array}{c}\text { مقترح من } \\
\text { لعام } \\
2025\end{array}$ & تخفيض مقررات السيناريو 20 & $\begin{array}{c}\text { م منرح } \\
\text { من لعام } 2025\end{array}$ & الأكتفاء الذاتي 1: & المقترحيب المحصولي 2025 & المحصول \\
\hline-14 & 87798 & 13 & 115159 & -8 & 94548 & -6 & 96354 & 102354 & البرســــيم (مستديم+تحريش) (ش) \\
\hline-2 & 582528 & -1 & 590043 & 1 & 597324 & 0 & 593710 & 593710 & 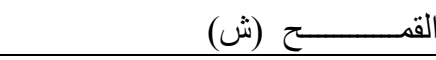 \\
\hline-3 & 2112 & 28 & 2784 & -10 & 1958 & 0 & 2180 & 2180 & الثــــــــعير (ش) \\
\hline-17 & 805 & -2 & 955 & 50 & 1458 & 1156 & 12188 & 970 & الفول البلدى (ش) \\
\hline-13 & 6795 & -4 & 7452 & 0 & 7769 & -1 & 7700 & 7769 & 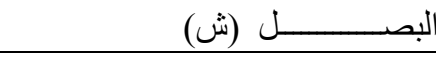 \\
\hline-12 & 9898 & -19 & 9083 & -3 & 10842 & -0.05 & 11195 & 11200 & 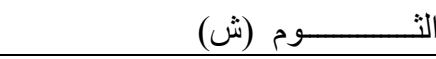 \\
\hline 75 & 154792 & -2 & 86809 & -1 & 87524 & 0 & 88520 & 88520 & بنجـر الســكر (ش) \\
\hline-13 & 15628 & -2 & 17552 & 2 & 18289 & -18 & 14800 & 18000 & الطماطم (ش) \\
\hline-33 & 80718 & -2 & 117592 & 4 & 125284 & -2 & 118018 & 120418 & اخري (ش) \\
\hline 74 & 16089 & -5 & 8742 & 1 & 9367 & 2 & 9462 & 9242 & خضروات أخرى (ش) \\
\hline \multirow[t]{2}{*}{-10} & 25066 & -6 & 26058 & 0 & 27866 & 1 & 28102 & 27866 & محاصـيل أخرى (ش) \\
\hline & 982229 & & 982229 & 0 & 982229 & & 982229 & 982229 & جملة مساحة المحاصيل الثتوية \\
\hline-2 & 698501 & 8 & 767831 & 1 & 715709 & -0.1 & 711434 & 712040 & الذرة الثــاميـــة (ص) \\
\hline-1 & 29854 & 14 & 34335 & 9 & 32984 & -0.3 & 30065 & 30146 & الذرة الرفيعــــــة (ص) \\
\hline 24 & 17198 & -42 & 8125 & -7 & 12909 & -1 & 13831 & 13925 & الفــول السـودانى (ص) \\
\hline 20 & 12025 & -38 & 6152 & -1 & 9875 & -0.2 & 9964 & 9980 & 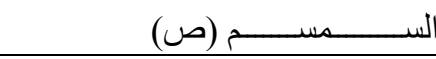 \\
\hline 22 & 38498 & -52 & 15145 & -3 & 30821 & -0.4 & 31542 & 31654 & فــــول الصــــويا (ص) \\
\hline 52 & 4454 & -66 & 985 & -28 & 2098 & -2 & 2871 & 2921 & عبــاد الثـــــــس (ص) \\
\hline-2 & 7092 & -26 & 5358 & 23 & 8925 & 8 & 7800 & 7230 & البط لــــــاطـــــــس (ص) \\
\hline-14 & 10254 & -29 & 8551 & 21 & 14515 & 0.03 & 11988 & 11985 & 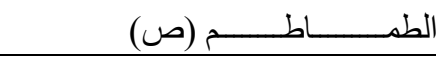 \\
\hline
\end{tabular}


تابع جذول رقم (5)

\begin{tabular}{|c|c|c|c|c|c|c|c|c|c|}
\hline \% لعام مق مقرح 2025 & محاصيل التيادة إنتاج & $\begin{array}{c}\text { \% مقرح لعام } 2025 \\
2025\end{array}$ & محاصيل الأعلافة إنتاج & $\begin{array}{c}\text { مقر من } \\
\text { من لعام } \\
2025\end{array}$ & 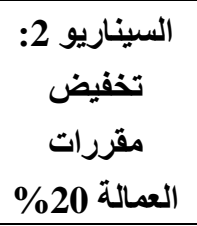 & $\begin{array}{l}\text { مقترح من } \\
\text { مقام } \\
2025\end{array}$ & الأكتفاء الذاتي 1اني & 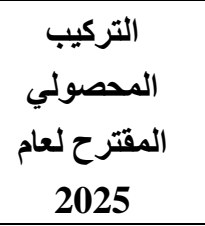 & المحصـول \\
\hline 35 & 29898 & -28 & 15889 & 3 & 22810 & 1 & 22430 & 22210 & خضروات أخرى (ص) \\
\hline-1 & 10480 & -38 & 6556 & 32 & 13925 & 4 & 10977 & 10582 & محاصيل أخرى (ص) \\
\hline-14 & 452 & -44 & 296 & -8 & 483 & 16 & 609 & 525 & 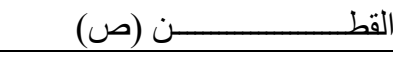 \\
\hline \multirow[t]{2}{*}{-9} & 54707 & -27 & 44190 & -20 & 48359 & -1 & 59902 & 60215 & 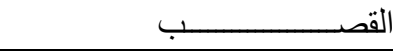 \\
\hline & 913413 & & 913413 & 0 & 913413 & & 913413 & 913413 & جملة مساحة المحاصيل الصيفية \\
\hline 0 & 9954 & 0 & 9954 & 18 & 11776 & 0 & 9954 & 9954 & 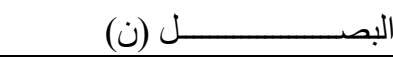 \\
\hline \multirow[t]{2}{*}{0} & 77034 & 0 & 77034 & -2 & 75212 & 0 & 77034 & 77034 & البطـــــــاطـــــــس (ن) \\
\hline & 86988 & & 86988 & 0 & 86988 & & 86988 & 86988 & جملة مساحة المحاصبل النيلية \\
\hline-84 & 752 & 86 & 8627 & -55 & 2060 & 0 & 4627 & 4627 & جملة البرسيم الحجازى \\
\hline 4 & 111695 & -3 & 104870 & 2 & 110268 & 0 & 107670 & 107670 & جملة مســاحة الحدائـق ق \\
\hline-5 & 2779 & -41 & 1729 & -1 & 2898 & 0 & 2929 & 2929 & جمـلة مسـاحة النخيل \\
\hline
\end{tabular}

\begin{tabular}{|c|c|c|c|c|c|c|c|c|c|}
\hline & 2097.856 & & 2097.856 & & 2097.856 & & 2097.856 & 2097.856 & المساحة المحصولية (الف فدان) \\
\hline-0.2 & 5209.097 & -2 & 5107.611 & -2 & 5115.823 & -0.3 & 5203.868 & 5218.706 & حجم المياه اللازمه للري (مليون م 3) \\
\hline-2 & 114.026 & -5 & 110.437 & -27 & 91.373 & -0.7 & 115.267 & 116.041 & حجم العمالة (مليون يوم عمل) \\
\hline-6 & 7.432 & -2 & 7.682 & -0.3 & 7.830 & -0.9 & 7.789 & 7.856 & صافتي العائد (مليار جنية) عند 50 \% \\
\hline-6 & 9.909 & -2 & 10.242 & -0.3 & 10.440 & -0.9 & 10.385 & 10.475 & إنتاجية للفداند (مليار جنية) عند 100 \% \\
\hline
\end{tabular}


نظيرتها للتركيب المحصولي المقترح لعام 2025، كما

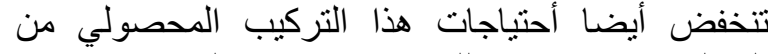
العمالة بنحو 2\%، وكذللك يتناقص صافي العائد نتيجة تبني

هذه السياسة بنحو 6\% \% \% خلاصة القول: تشير النتائج إلي أن تبني الدولة لسياسة

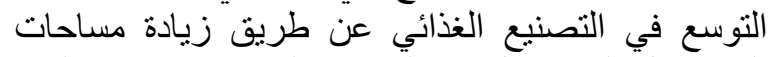

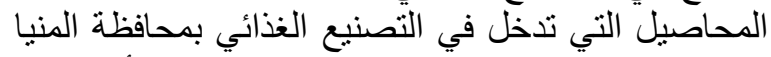

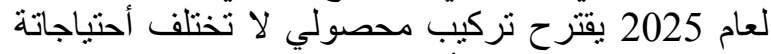

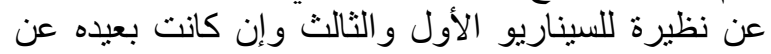

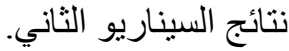

\section{7. نتائج البحث والتوصيات}

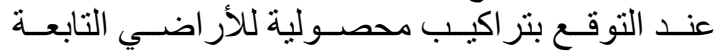

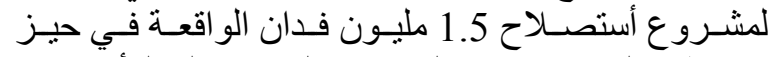

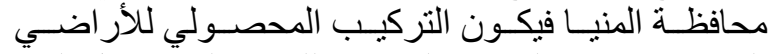

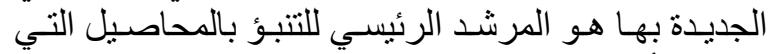

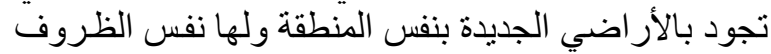

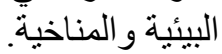

التركيب المحصولي الأفضل لمحافظة المنيا لعام 2025

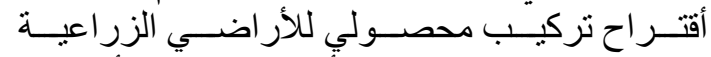

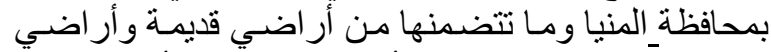
جديدة، وبعد إضـافة الـ 620 ألف فدان المقرر أستصـاحها

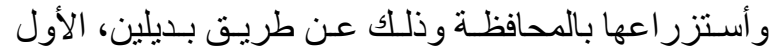

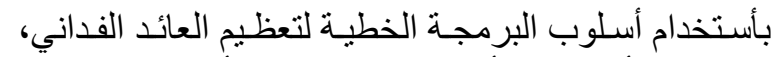

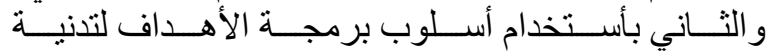

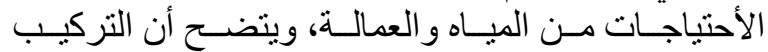

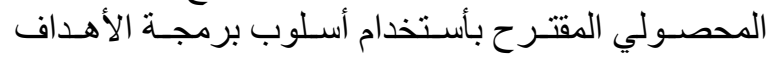

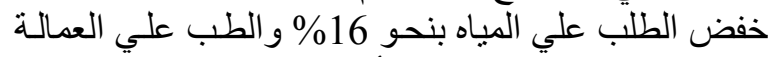
بنحو 27\%، ولكن مقابل ذلك أنخفض صافي العائد المنوقع العيا

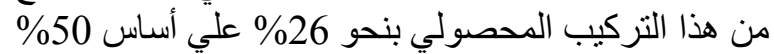

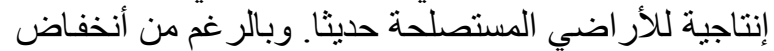

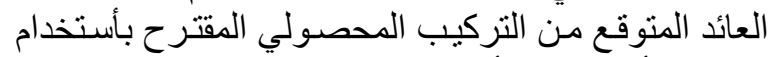

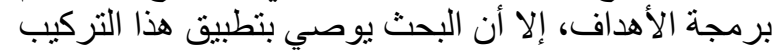

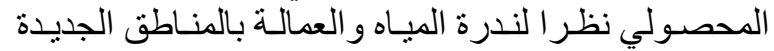

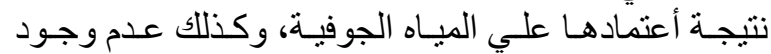

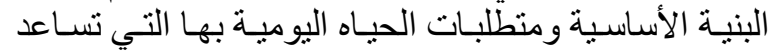

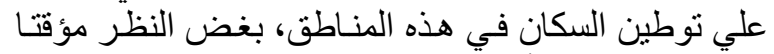

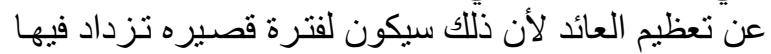

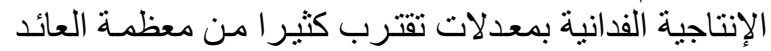

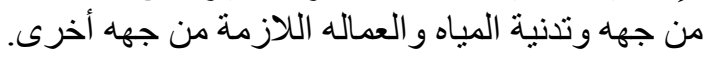

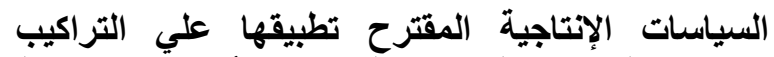
المحصولية المختلفة لمحافظة المنئة المنيا للأراضي المياتي الزراعية القديمة والجديدة والمستصلحة من مشروع الـ لـ 1.5 مليون الزعاع

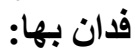
السيناريو الأول: إقتراح تركيب محصولي يتبني سياسة

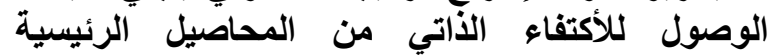

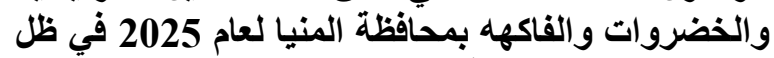

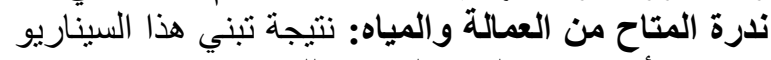

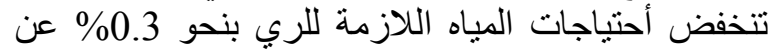
نظيرتها للتركيب المحصولي المقترح لعام 2025، كما لإن
المحصولي من العمالة بنحو 5\%، وكذللك يتناقص صافي العائد نتيجة تبني هذه السياسة بنحو 2\% \%

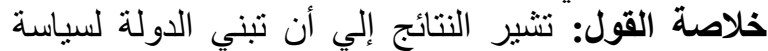

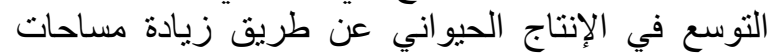
محاصيل الأعلاف بمحافظة الإنياج المنيا لعام 2025 يقتر زئرة

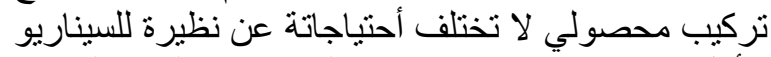

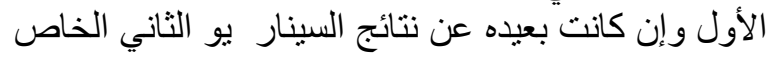

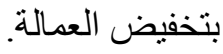

6. 5. 4. السيناريو الرابع: إقتراح تركيب محصولي يتبني

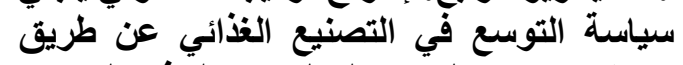
زيادة مساحات المحاصيل التي تلخل في التئي التصنيع طريق الغذائي بمحافظة المنيا لعام 2025 في ظلئ فل ندرة المتاح من العمالة والمياه

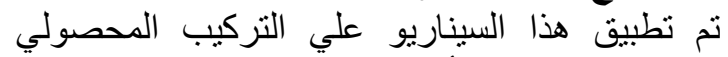

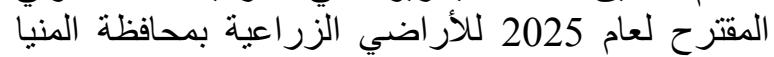

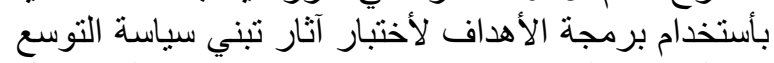

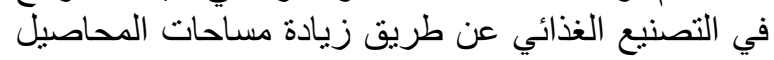
التي تدخل في التصنيع الغذائي بمحافظة المنيا لعام التيا 2025

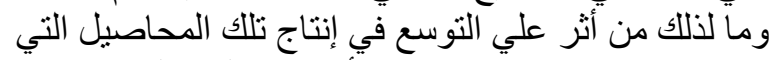

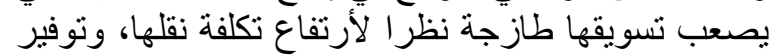

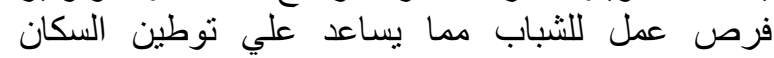

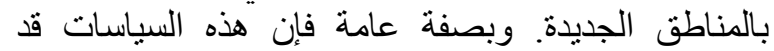

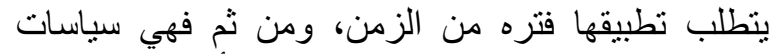

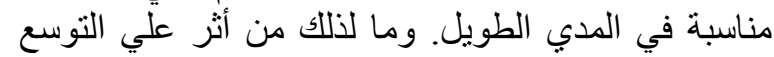

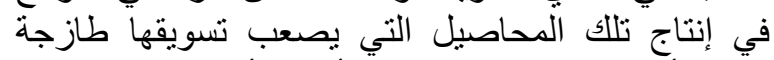

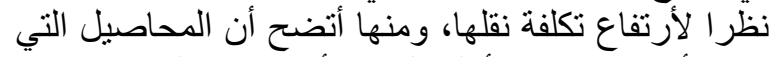

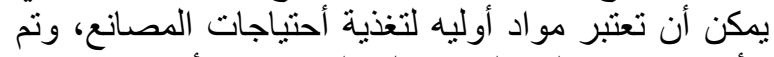

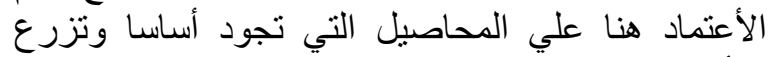

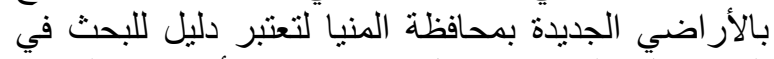

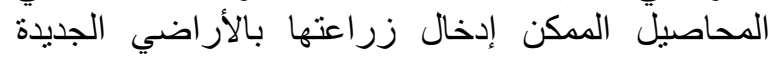

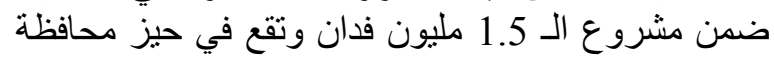

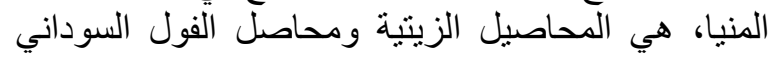

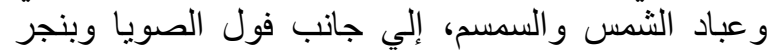
السكر و الخضرو ات الصيفية و الثتوية و الفاكهه. نوضح النتائج بجدول (5) أن الن مساحة بنجر النيكة السكر

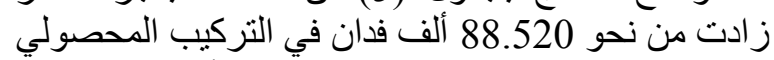

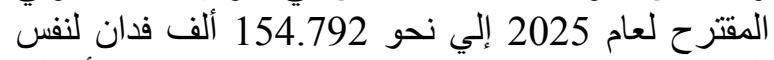

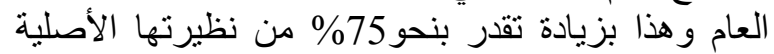
لعام 2025. كما أرتفعت مساحة الفول السوداني و والسمسم

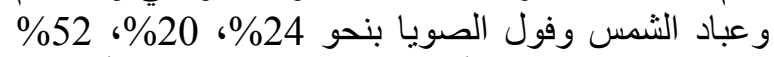

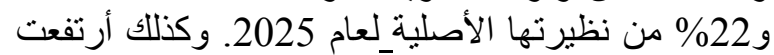

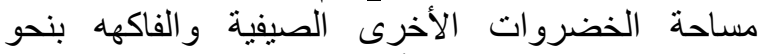
35\%، \% \% من نظيرتها الأصلية لعام 2025.

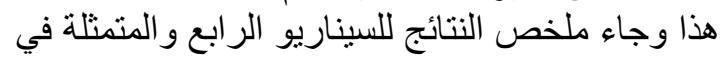

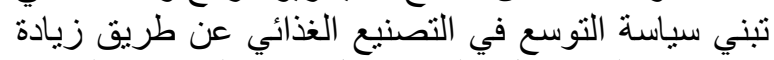

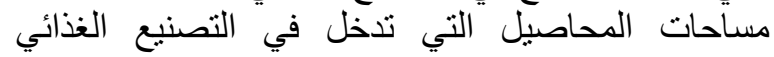

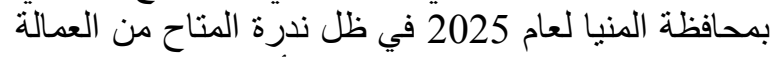

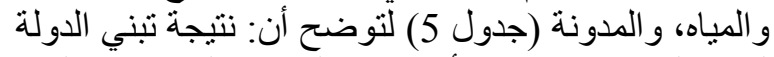

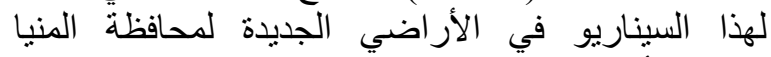
تنخفض أحتياجات المياه اللازمة للري بنحو 0.2\% عن الجئ 
الرحاصيل التي تدخل في التصنيع الغذائي، مما يؤدي إلي

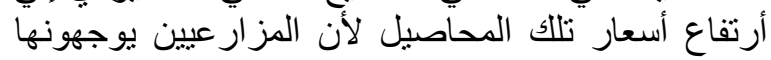

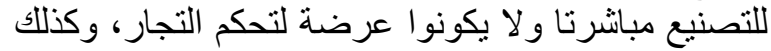

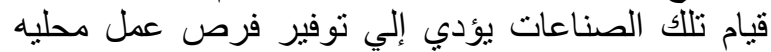
أكثر ، و هذا ما يقلل نسبة البطالة.

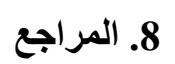

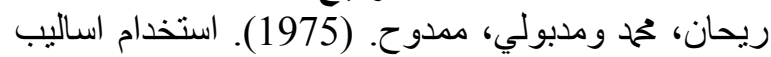

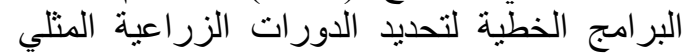

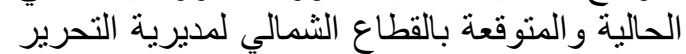

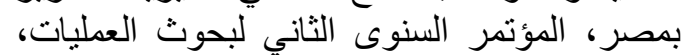

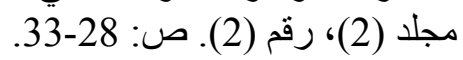

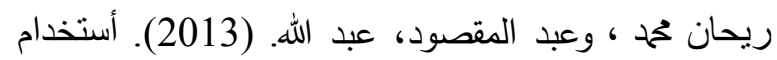

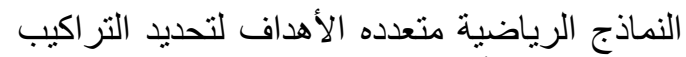

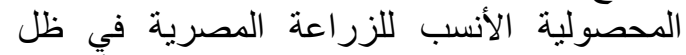
سيناريوهات مختلفة للموارد المائية والألية الأرضية

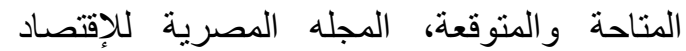

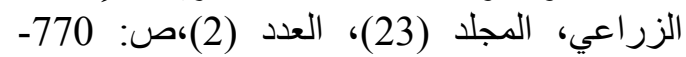
775

سالي، بوادي. (2006). التراكيب المحصولية المتلي للزراعة المصرية في ضواء التوائ التوسعات الحالية

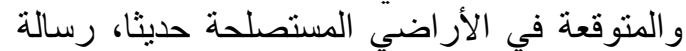

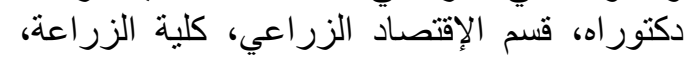

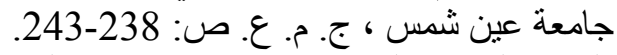

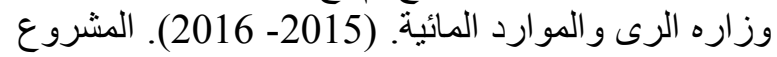
القومي لزر اعة المليون ونصف الملية (2015 اليون فدان. ص:

\section{REFERENCES}

Frederick S. and Gerald J. (2000). Introduction To Operations Research, publishing company, Oxford, edition 7, pp:57-89.

Murty K. G., (1995). Operations Research Deterministic Optimization Models, USA: Prentice- Hall, pp:102-119.

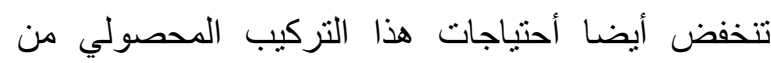

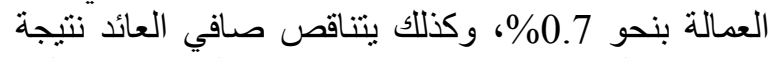

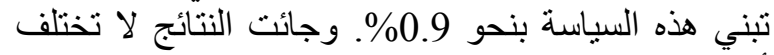
أحتياجاته النهائية من المياه والعمالة والة وصافي والئي العائد عن

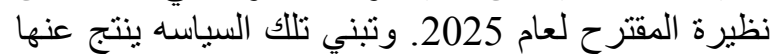
توفير الخضر و الفاكها و المحاصيل الأستر اتيجية للمحافظة

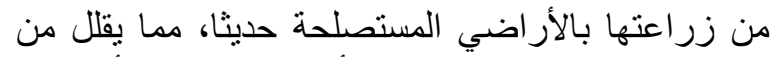

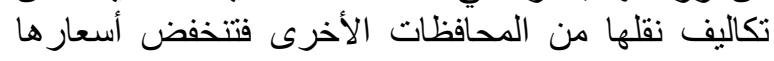
النهائية التي يدفعها المستهلكا.

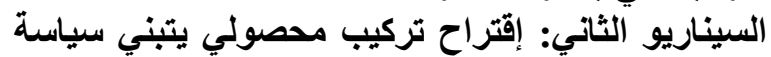

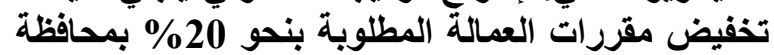

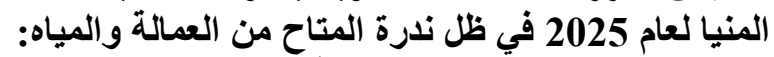

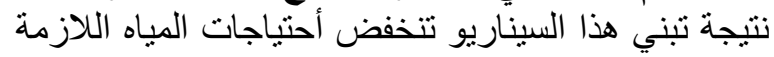

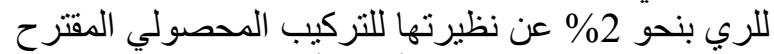

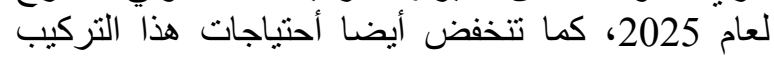

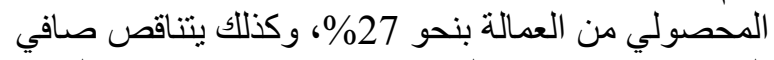
العائد نتيجة تبني هذه السياسة بنحو 0.3\% و

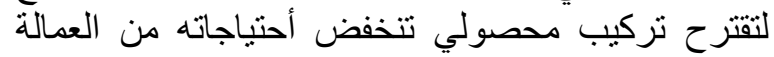

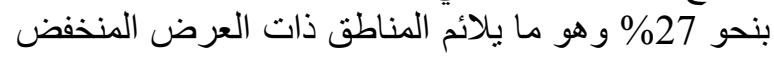

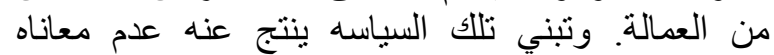

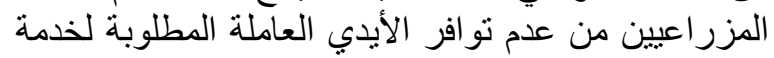

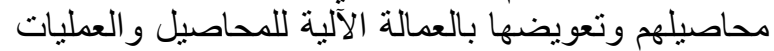

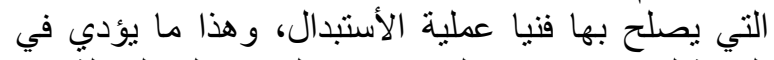

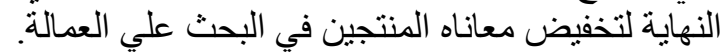

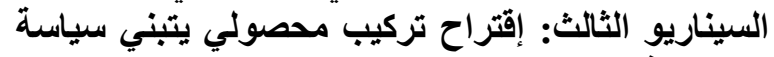

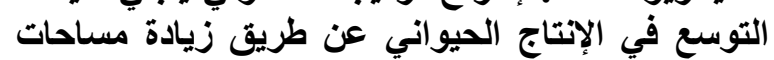

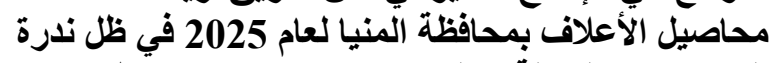

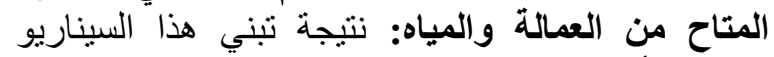

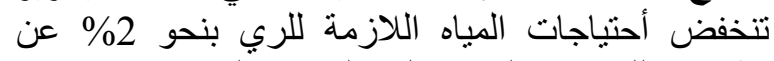

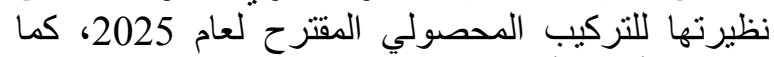

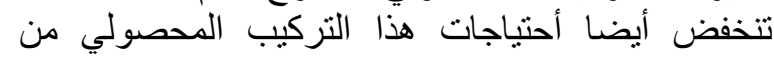

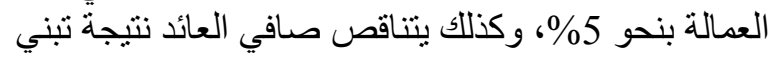

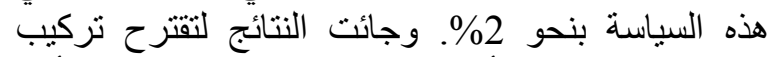
محصولي لا تختلف أحتياجاتة عن نظيرة للنسيناريو الأول

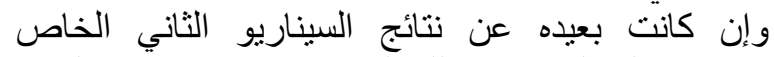

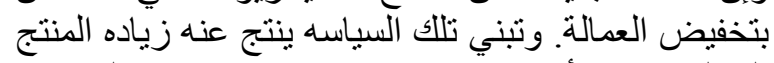

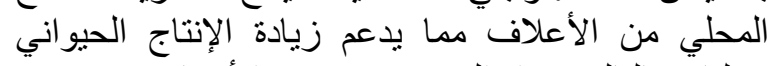

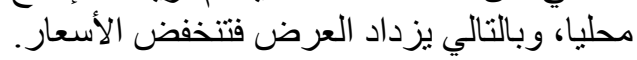
السيناريو الرابع: إقتراح تركيب محصولي يتبني لئي سياسة

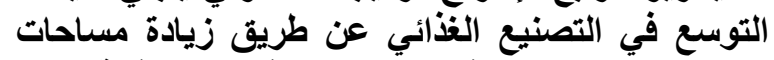

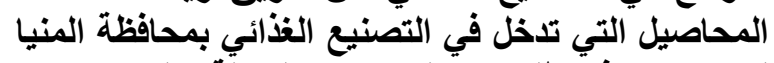

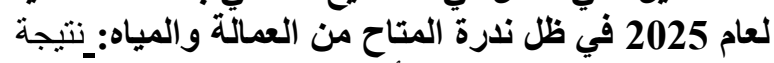

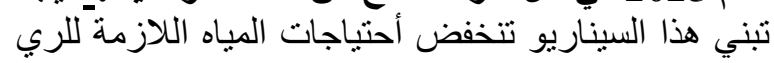

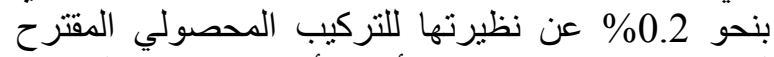

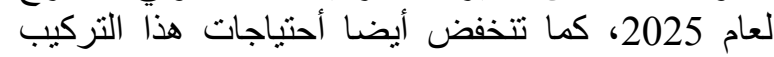

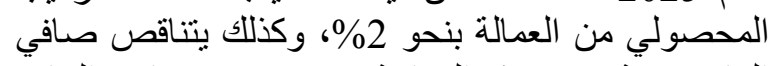

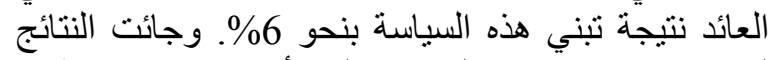

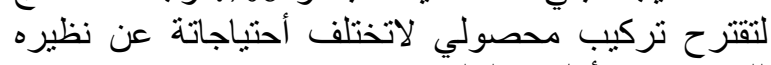

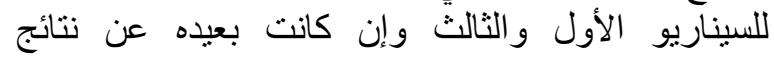

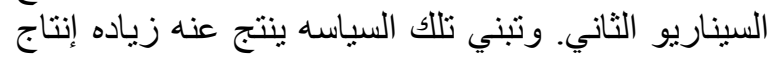

